\title{
Survey for Freshwater Mussels (Unionidae) in the Lower Green and Barren Rivers, Kentucky, 1992
}

by Andrew C. Miller, Barry S. Payne Environmental Laboratory

Approved For Public Release; Distribution Is Unlimited 
The contents of this report are not to be used for advertising, publication, or promotional purposes. Citation of trade names does not constitute an official endorsement or approval of the use of such commercial products.

\section{PRINTED ON RECYCLED PAPER}




\section{Survey for Freshwater Mussels (Unionidae) in the Lower Green and Barren Rivers, Kentucky, 1992}

by Andrew C. Miller, Barry S. Payne

Environmental Laboratory

U.S. Army Corps of Engineers

Waterways Experiment Station

3909 Halls Ferry Road

Vicksburg, MS 39180-6199

\section{Final report}

Approved for public release; distribution is unlimited 


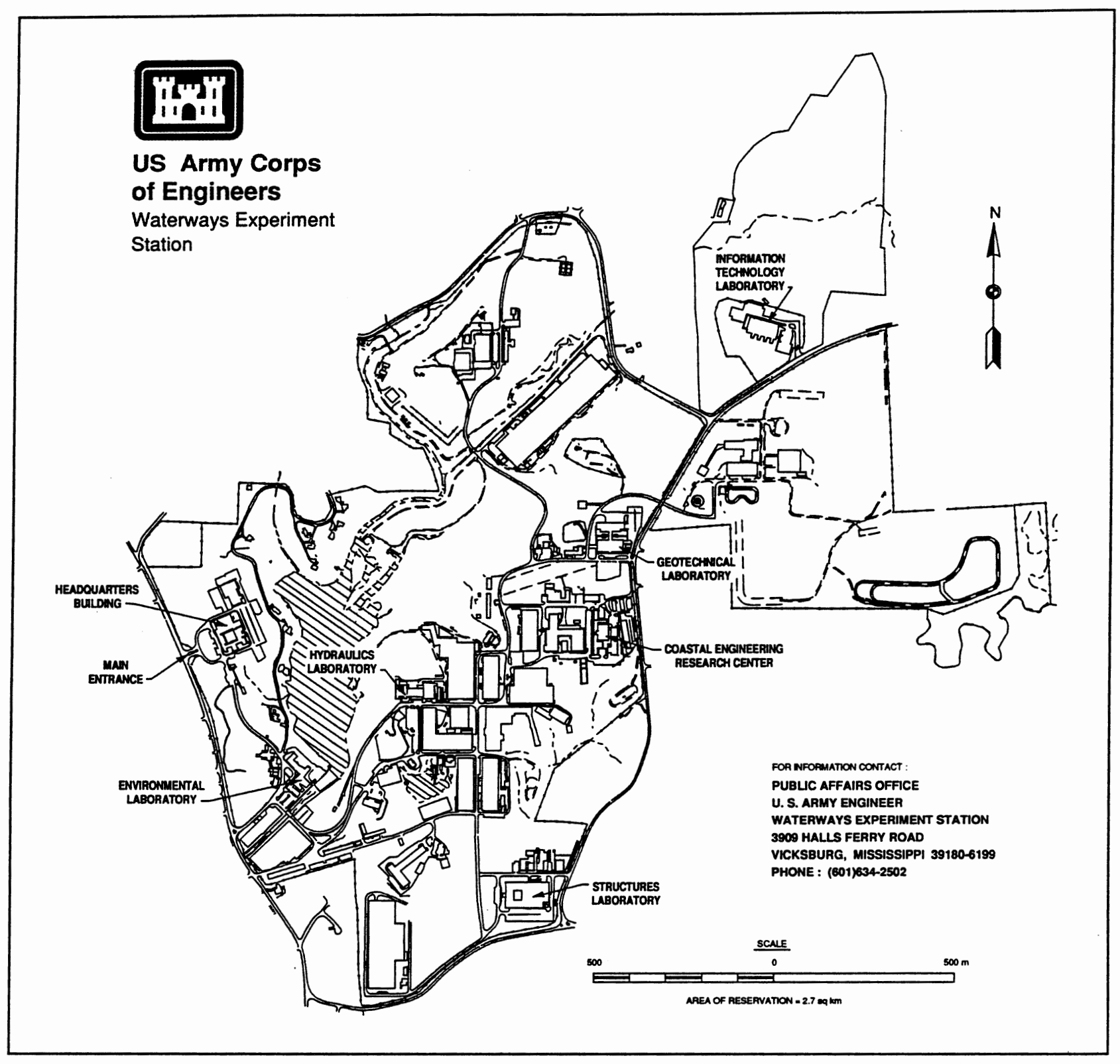

\section{Waterways Experiment Station Cataloging-in-Publication Data}

Miller, Andrew C.

Survey for freshwater mussels (Unionidae) in the Lower Green and Barren Rivers, Kentucky, 1992 / by Andrew C. Miller, Barry S. Payne ; prepared for U.S. Army Engineer District, Louisville.

60 p. : ill. ; $28 \mathrm{~cm}$. - (Technical report ; EL-93-8) Includes bibliographical references.

1. Unionidae - Kentucky - Green River (River) 2. Freshwater mussels - Kentucky - Geographical distribution - Statistics. 3. Mussels - Kentucky - Barren River (River) I. Payne, Barry S. II. United States. Army. Corps of Engineers. Louisville District. III. U.S. Army Engineer Waterways Experiment Station. IV. Title. V. Series: Technical report (U.S. Army Engineer Waterways Experiment Station) ; EL-93-8. TA7 W34 no.EL-93-8 


\section{Contents}

Preface ..................... v

Conversion Factors, Non-SI to SI Units of Measurement . . . . . . vi

1 -Introduction . .................... 1

Historical Information on Mussels of the Green

and Barren Rivers . . . . . . . . . . . . . . . . . 1

Purpose and Scope . . . . . . . . . . . . . . . . 2

2-Study Area and Methods ............... 3

Study Area ......................... 3

Location of Sampling Sites ............... . . 3

Methods ...................... 9

Background ....................... 9

Site selection rationale ............... 9

Qualitative mussel collections .............. 9

Quantitative mussel collections ... . . . . . . . . 10

Sample processing .................. 10

Data analysis ...................... 10

3 -Bivalve Community . . . . . . . . . . . . 15

Results Obtained with Qualitative Sampling Methods . . . . . . 15

Areas with low density . . . . . . . . . . . . 15

Areas with moderate density . . . . . . . . . . . 15

Results Obtained with Quantitative Sampling Methods . . . . . . 17

Bivalve density . . . . . . . . . . . . . 17

Community characteristics . . . . . . . . . . . . 19

Size demography of dominant populations

downriver of Dam No. $3 \ldots \ldots \ldots$. . . . . . . . 30

4 -Discussion ............................ 37

Comparison with Results of Study by Williams (1969) . . . . . . . 37

Population and Community Dynamics . . . . . . . . . . . . . 40

Community composition .............. 40

Species richness . . . . . . . . . . . . . . . . 40

Relative species abundance .............. 40 
Density ...................... 41

Population demography .............. 41

Concluding Comments . . . . . . . . . . . . . . . 41

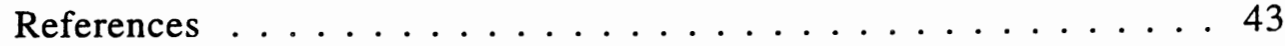

Appendix A: Results of Qualitative Searches for Mussels

in the Green and Barren Rivers, Kentucky, 1992 . . . . . . . . . Al

SF 298 


\section{Preface}

In June and July 1992, personnel of the U.S. Army Engineer Waterways Experiment Station (WES) conducted a survey for freshwater mussels (Family: Unionidae) between River Mile (RM) 100 and 155 in the Green River and RM 0.0 and 9.0 in the Barren River, KY. Data will be used by the U.S. Army Engineer District, Louisville (CEORL), to assess the environmental effects of replacing Lock and Dam No. 3, located at Green RM 108.5.

Divers were Messrs. Larry Neill, Robert Warden, Robert T. James, and Jeff Montgomery from the Tennessee Valley Authority. Assistance in the field was provided by Messrs. Eric Pearson and Chuck Boston, University of Louisville.

Mr. Jim Baker, CEORL, assisted in the field, provided background information on the project, and reviewed an early draft of this report. Ms. Erica Hubertz, University of West Florida, measured and identified mussels in the laboratory. All figures except maps were prepared by Ms. Sarah Wilkerson, Environmental Laboratory (EL), WES.

Ms. Deborah Shafer, EL, diving inspector, assisted in the laboratory and field.

This report was prepared by Drs. Andrew C. Miller and Barry S. Payne, Aquatic Ecology Branch (AEB), Environmental Resources Division (ERD), WES. During the conduct of this study, Dr. E. A. Theriot was Chief, AEB; Dr. C. J. Kirby was Chief, ERD; and Dr. John Harrison was Director, EL.

Director of WES was Dr. Robert W. Whalin. COL Leonard G. Hassell, EN, was Commander.

This report should be cited as follows:

Miller, A. C., and Payne, B. S. 1993. "Survey for freshwater mussels (Unionidae) in the lower Green and Barren Rivers, Kentucky, 1992," Technical Report EL-93-8, U.S. Army Engineer Waterways Experiment Station, Vicksburg, MS. 


\section{Conversion Factors, Non-SI to SI Units of Measurement}

Non-SI units of measurement used in this report can be converted to SI units as follows:

\begin{tabular}{|l|l|l|}
\hline Multiply & By & To Obtain \\
\hline feet & 0.3048 & meters \\
\hline inches & 25.4 & millimeters \\
\hline miles (U.S. statute) & 1.609347 & kilometers \\
\hline square miles & 0.8361274 & square kilometers \\
\hline yards & 0.9144 & meters \\
\hline
\end{tabular}




\section{Introduction}

\section{Historical Information on Mussels of the Green and Barren Rivers}

Between 1921 and 1925, A. E. Ortmann and W. J. Clench collected freshwater mussels (family: Unionidae) by hand at seven sites in the Green River upriver of Mammoth Cave, Kentucky, and at two sites in the Barren River (Ortmann 1926). All of the sites that they studied were outside the area surveyed during this study made by the U.S Army Engineer Waterways Experiment Station (WES) in June and July 1992. Ortmann listed 66 species and reported that the fauna resembled those in the Kentucky, Licking, and Big Sandy Rivers in the Ohio and the Interior Basin and had no relation to the Cumberlandian unionidae.

Clench and van der Schalie (1943) reported the results of a trip to the Green River made by William J. Clench and Peter Okkelberg. Clench and van der Schalie (1943) listed the unionids collected during that trip and compared findings with those reported by Ortmann (1926). In addition, they concurred with Ortmann (1926) that the Green River fauna was distinctive from that in the Cumberland River.

Stansbery (1965) collected in the Green River at Munfordville, upriver of the WES study area. He considered this reach of the river to support one of the "finest representative Ohioan naid fauna in existence." In 1968, Williams (1969) collected mussels in the Green River using divers and a brail. Two of the reaches (Area I and II) he surveyed were upriver of the area WES personnel studied. However, his Area III included all of the areas that WES researchers surveyed in the Green River in 1992. Isom (1974) summarized results of previous studies and reported that 77 species of Unionidae, and the Asian clam Corbicula fluminea had been reported from the Green River. In 1981-82, the Academy of Natural Sciences (1983) studied a reach of the Green River downriver of River Mile (RM) 67.5. Their study was designed to collect background information on hydrology and aquatic resources, including freshwater mussels, for the proposed International Coal Refining Company plant. Mussel surveys have been conducted recently in the Barren River (Weiss and Layzer 
1992) and the Green and Barren Rivers (Cochran and Layzer 1992), both

outside the WES study area.

When Williams (1969) surveyed in 1968, he reported that the lower reach of the Green River was heavily used by commercial towboats. At that time, commercial traffic had used the lower river for over 100 years; locks and dams were built in the early 1800 s. In the 24 years between the surveys by Williams and WES, the reach immediately downriver of Dam No. 3 has been virtually free of commercial vessels. Effects of nonpoint sources of pollution from oil wells (seepage and overland flow) were not found in the Green River by Isom (1974).

\section{Purpose and Scope}

The U.S. Army Engineer District, Louisville (CEORL), proposes to replace Lock and Dam No. 3 on the Green River. Dredging will probably be required at selected sites to maintain the navigation pool. The new pool will be at the same elevation that Dam No. 3 was originally designed to provide (380.4 $\mathrm{ft}^{1}$ mean sea level (MSL)). Water levels in the Green River upriver of Dam No. 3 and in the lower Barren River will be unaffected. No modifications have been proposed for Dam No. 4, located at RM 149.0.

The purpose of this report is to describe location, community composition, density, and recruitment of freshwater bivalves (mainly the family Unionidae, but also including the Asian clam C. fluminea) in the lower Green and Barren Rivers, Kentucky. These data will be used by personnel of the CEORL to assess the environmental effects of replacing Lock and Dam No. 3.

\footnotetext{
1 A table of factors for converting non-SI units of measurement to SI units is presented on page vi.
} 


\section{Study Area and Methods}

\section{Study Area}

The Green River originates south of Danville in central Kentucky. It flows southwest to Campbellsville, KY, and then in a westerly, then northwesterly direction until its confluence with the Ohio River upriver of Evansville, IN (Figure 1). The lower one-third of the Green River is low gradient with steep, tree-lined banks. In this reach the river is approximately $200 \mathrm{ft}$ wide. The bottom consists of sand, gravel, and silt, with occasional patches of bedrock and clay.

Presently there are two functional dams on the Green River. Dam No. 1 is located at RM 9.1, near Spotsville, Henderson Co., KY, and maintains a normal pool of $349.1 \mathrm{ft}$. Dam No. 2 is located at RM 63.1, near Rumsey in McLean Co., KY, and maintains a normal pool elevation of $363.4 \mathrm{ft}$. Dam No. 3, which is not in operation, is located at RM 108.5 near Skilesville in Muhlenberg Co., KY. This lock was closed and placed in caretaker status on 1 October 1981. Normal pool elevation $(379.9 \mathrm{ft}$ MSL) between Dam Nos. 3 and No. 4 is still being maintained. Dam No. 4, which is also not in operation, is located at RM 149.0 near Woodbury in Butler Co., KY. This dam failed in May 1965, and the normal pool elevation ( $396.8 \mathrm{ft}$ MSL) could not be maintained.

The Barren River originates just south of the Kentucky-Tennessee Border and flows in a north-westerly direction and enters the Green River just upriver of Dam No. 4 at about RM 149.6.

\section{Location of Sampling Sites}

The survey was conducted between RM 100 and 155 in the Green River and between RM 0 and 9 on the Barren River (Figure 2). Qualitative searches for mussels were made at 27 sites, 7 on the Barren River and 20 on the Green River (Figure 1). At three sites on the Green River (RM 101.5, 105.5, and 107.4), densities were high enough to enable the divers to collect 10 to 12 discrete samples using qualitative methods. In 


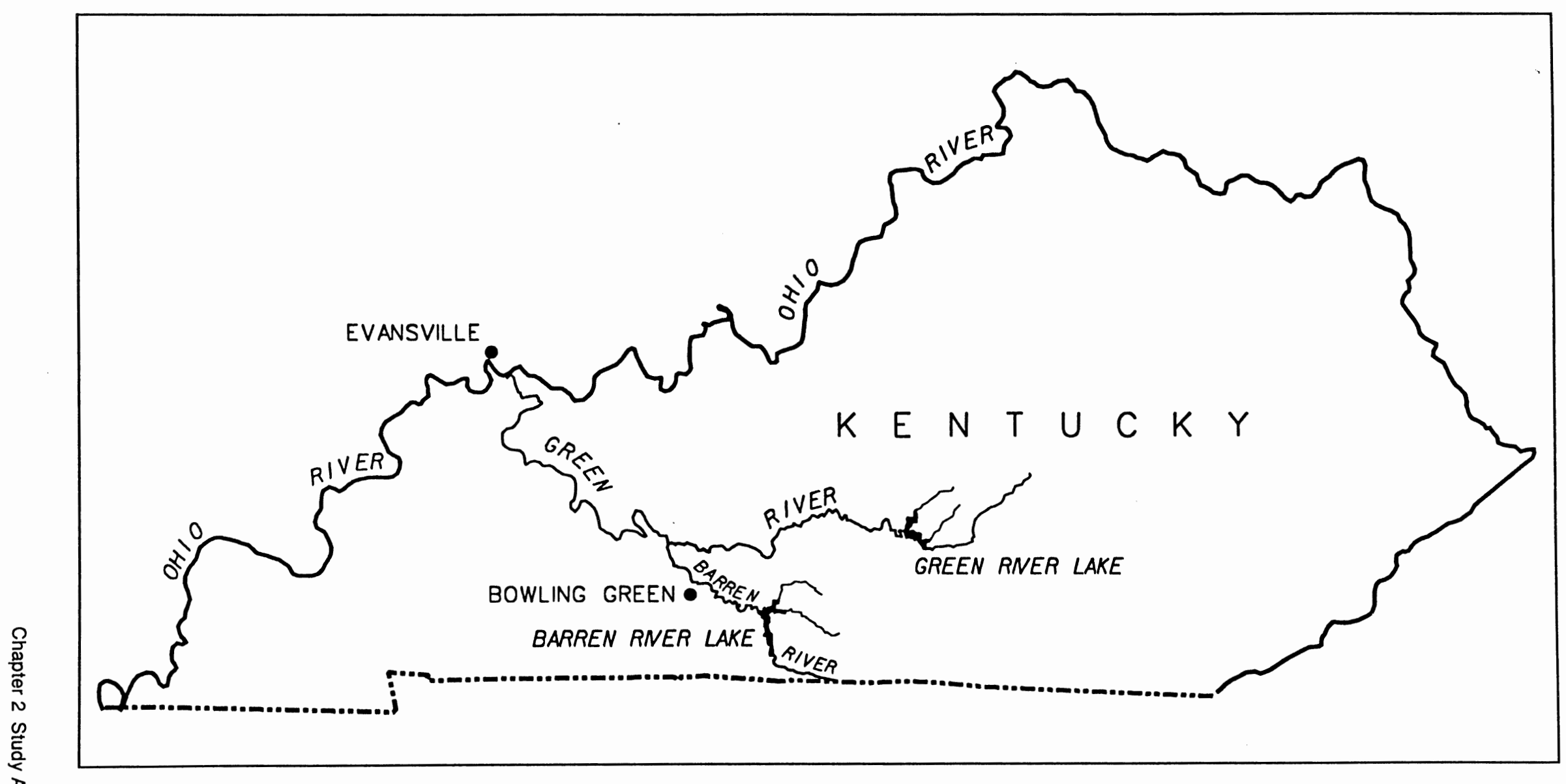

Figure 1. Map of Kentucky showing the Green and Barren Rivers 


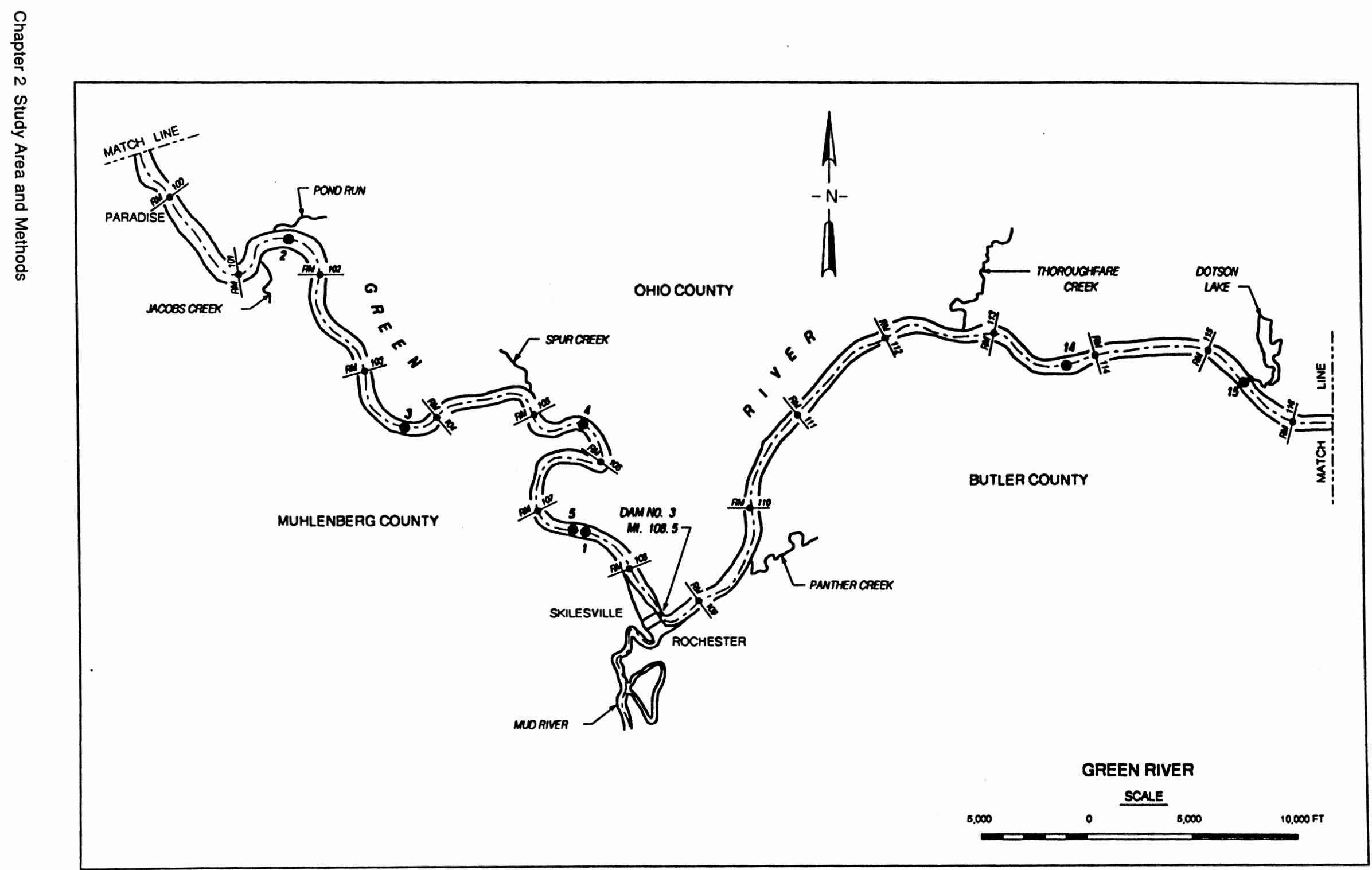

Figure 2. Sites on the Green and Barren Rivers that were surveyed for bivalves (Sheet 1 of 4 ) 


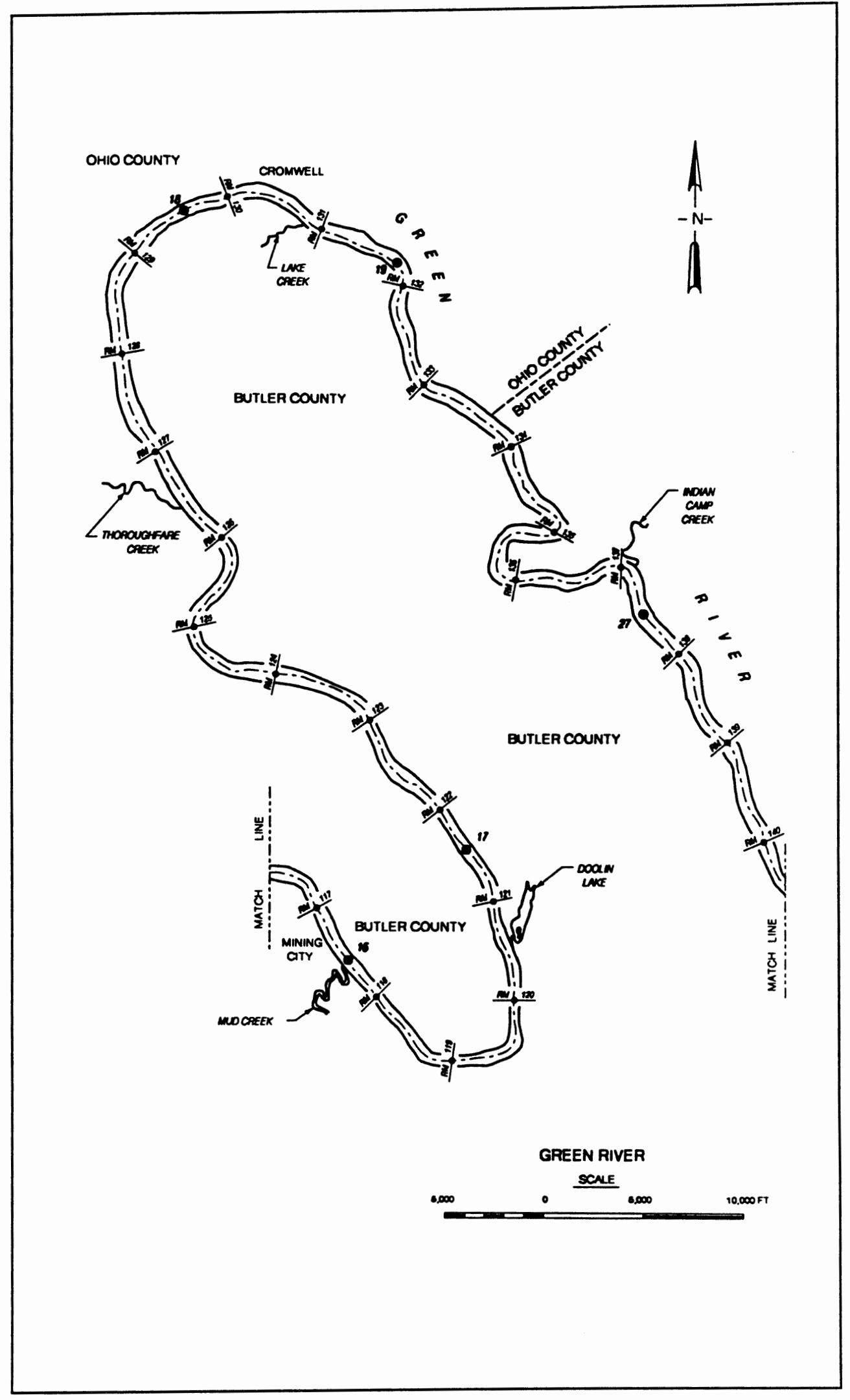

Figure 2. (Sheet 2 of 4) 


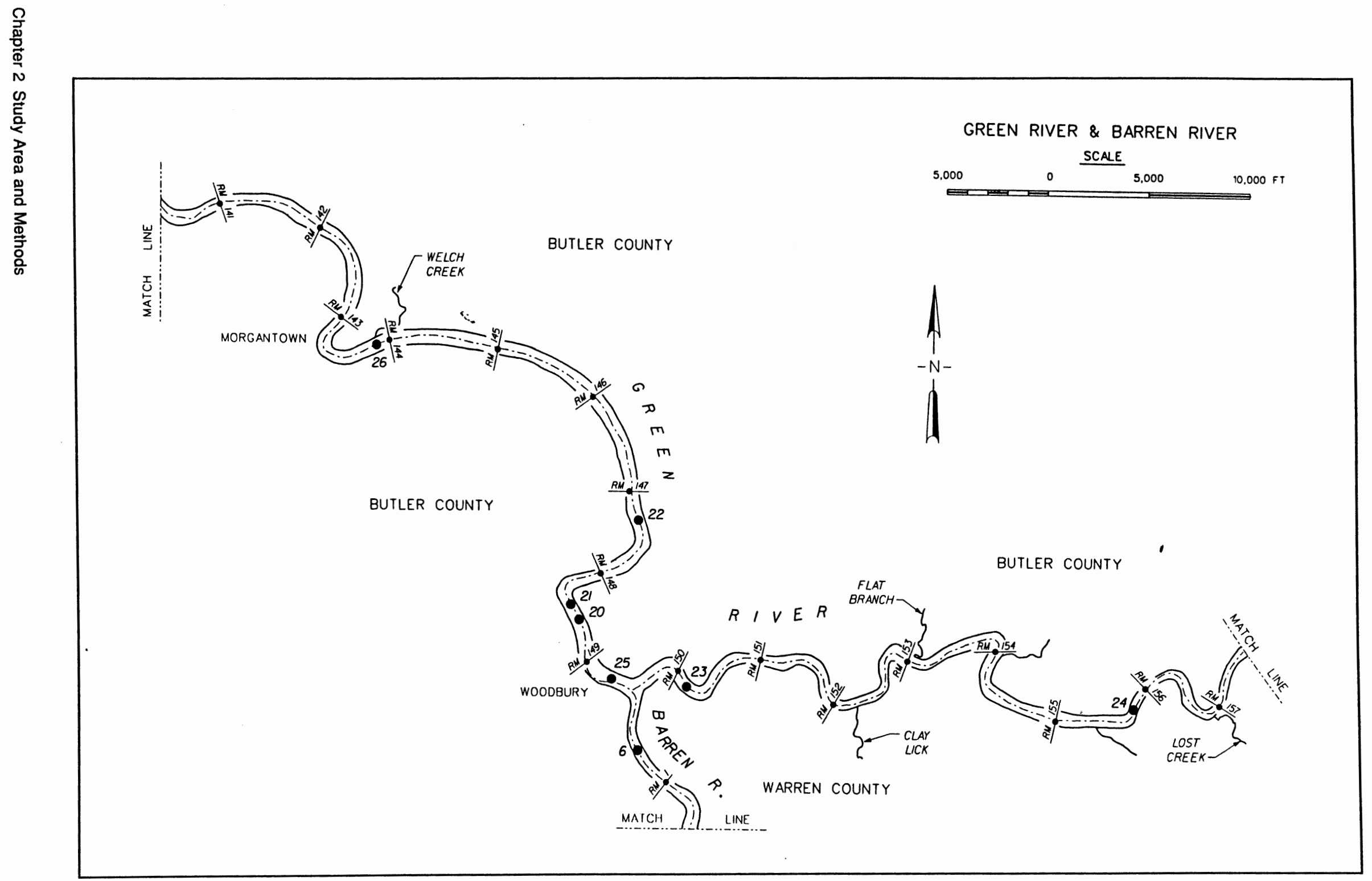

Figure 2. (Sheet 3 of 4) 


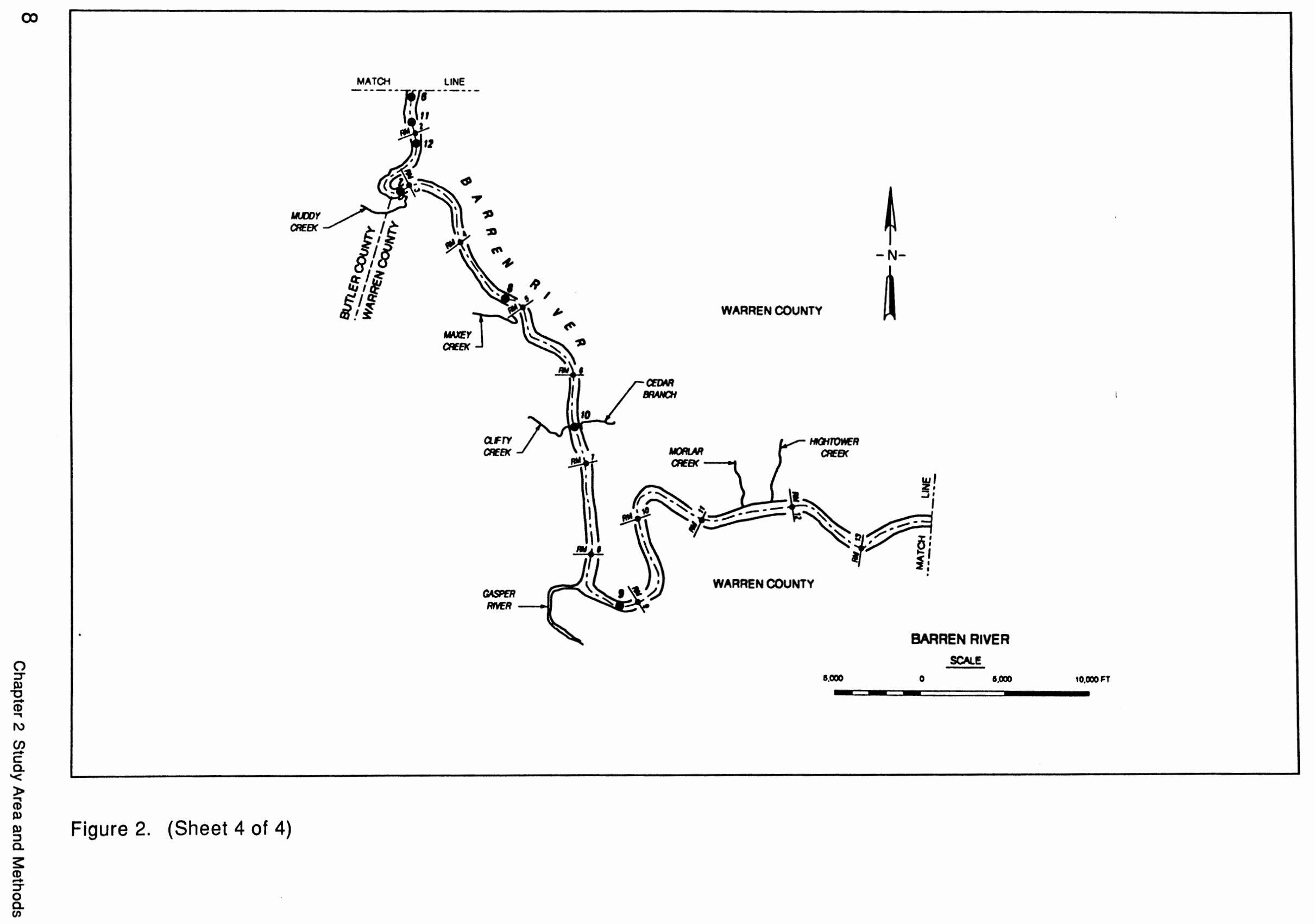


addition, quantitative samples were obtained at beds located immediately downriver of Dam Nos. 3 and 4.

\section{Methods}

\section{Background}

All underwater work was accomplished by a dive crew equipped with surface-supplied air and communication equipment. Divers could communicate with each other and tenders located on the dive boat. Depending on objectives and conditions, either one or two divers were in the water at one time. In addition to collecting mussels, divers provided information on current velocity, substratum conditions, and extent of mussel beds.

\section{Site selection rationale}

Sites likely to support dense and diverse mussel assemblages were identified by examining navigation charts supplied by the CEORL (Green River Navigation Charts, U.S. Army Engineer District, Louisville, 1989). Areas were judged to be suitable for underwater investigation if they were in a slightly pooled portion of the river immediately upriver of a constriction or bend or if substratum appeared to consist of coarse gravel or cobble.

Divers conducted a preliminary underwater investigation of areas identified from navigation charts. During this investigation, divers were instructed to search the bottom and retrieve all live mussels recognized by touch. Usually a single diver worked for $20 \mathrm{~min}$ or two divers worked for 10 min. Live mussels were placed in nylon bags and brought to the surface for identification. If unionid density appeared moderate to high, detailed studies were conducted. Methods for conducting these more detailed studies are described below:

\section{Qualitative mussel collections}

Three sites in the Green River were suitable for collecting using qualitative methods that were more intensive than those used during the preliminary investigation. At these sites two divers worked simultaneously and placed a specific number of live mussels in nylon bags. Five mussels were placed in three bags, and twenty mussels were placed in nine bags. Divers attempted to collect without bias to size or type. In addition, they excluded the Asian clam, $C$. fluminea, from these samples. If $C$. fluminea was inadvertently collected, it was later eliminated. 
All mussels were brought to the surface, counted, and identified. Data were recorded on standard data sheets and returned to the laboratory for analysis. Voucher specimens for each species were placed in plastic zipper-lock bags and labeled with high rag content paper. Mussels not needed for voucher were returned to the river. Methods for sampling mussels were based on techniques described in Coker (1919); Brice and Lewis (1979); Miller and Nelson (1983); Isom and Gooch (1986); Kovalak, Dennis, and Bates (1986); and Miller and Payne (1988). Mussel identification was based on taxonomic keys and descriptive information in Murray and Leonard (1962), Parmalee (1967), Starrett (1971), and Burch (1975). Nomenclature is consistent with Turgeon et al. (1988). A list of scientific and common names for all species collected during the survey appears in Table 1 .

\section{Quantitative mussel collections}

Quantitative methods were used to collect bivalves (unionids as well as C. fluminea), at 10 sites downriver of Dam Nos. 3 and 4 sites downriver of Dam No. 4 (Figures 3 and 4). No mussels were found at Site $1 \mathrm{im}$ mediately downriver of Dam No. 3; therefore, live mussels were found at only nine sites at this location. At each site, 0.25 -sq $\mathrm{m}$ quadrats were positioned approximately $1 \mathrm{~m}$ apart and arranged in a 2 by 5 matrix. A diver excavated all sand, gravel, shells, and live bivalves to a depth of 10 to $15 \mathrm{~cm}$. Material was sent to the surface in a $20 \mathrm{l}$ bucket and transported to shore. Sediment was screened through a sieve series (finest screen with apertures of $6.4 \mathrm{~mm}$ ). All live mussels and $C$. fluminea removed from samples were placed in $4 l$ zipper-lock bags.

\section{Sample processing}

Each bivalve was identified and total shell length (SL) measured to the nearest $0.1 \mathrm{~mm}$ with a dial caliper. After the mussels were processed, they were returned to the river. If time permitted, mussels were identified and measured during the day. If mussels could not be processed immediately after collection, they were preserved in 10-percent buffered formalin and returned to WES. In the laboratory, preserved specimens were rinsed with tap water and then identified, and total shell length was measured.

\section{Data analysis}

Species diversity was determined with the following formula:

$$
H^{\prime}=-p_{j} \log p_{j}
$$

where $H^{\prime}$ is species diversity and $p_{j}$ is the proportion of the population that is of the $j^{\text {th }}$ species (Shannon and Weaver 1949). Natural logarithms $\left(\log _{2.3026}\right)$ were used as recommended by Magurran (1988). 


\begin{tabular}{|c|c|c|c|}
\hline \multicolumn{4}{|c|}{$\begin{array}{l}\text { Table } 1 \\
\text { Scientific and Common Names for Bivalves Collected in the Green and } \\
\text { Barren Rivers, Kentucky, Using Qualitative and Quantitative Methods }\end{array}$} \\
\hline Scientific Name & Common Name & Qualitative & Quantitative \\
\hline Amblema p. plicata (Say 1817) & Threeridge & $x$ & $x$ \\
\hline Megalonaias nervosa (Rafinesque 1820) & Washboard & $x$ & $x$ \\
\hline Elliptio crassidens (Lamarck 1819) & Elephant-ear & $x$ & $x$ \\
\hline Obliquaria reflexa (Rafinesque 1820) & Threehorn wartyback & $x$ & $x$ \\
\hline Potamilus alatus (Say 1817) & Pink heelsplitter & $x$ & $x$ \\
\hline Lasmigona c. complanata (Barnes 1823) & White heelsplitter & $x$ & \\
\hline Quadrula p. pustulosa (I. Lea 1831) & Pimpleback & $x$ & $x$ \\
\hline Ellipsaria lineolata (Rafinesque 1820) & Butterfly & $x$ & $x$ \\
\hline Quadrula quadrula (Rafinesque 1820) & Mapleleaf & $x$ & $x$ \\
\hline Pleurobema cordatum (Rafinesque 1820) & Ohio pigtoe & $x$ & $x$ \\
\hline Elliptio dilatata (Rafinesque 1820) & Spike & $x$ & $x$ \\
\hline Quadrula nodulata (Rafinesque 1820 ) & Wartyback & $x$ & $x$ \\
\hline Leptodea fragilis (Rafinesque 1820) & Fragile papershell & $x$ & $x$ \\
\hline Actinonaias ligamentina (Lamarck 1819) & Mucket & $x$ & $x$ \\
\hline Arcidens confragosus (Say 1829) & Rock-pocketbook & $x$ & \\
\hline Truncilla truncata (Rafinesque 1820) & Deertoe & $x$ & $x$ \\
\hline Fusconaia ebena (1. Lea 1831) & Ebonyshell & $x$ & $x$ \\
\hline Tritogonia verrucosa (Rafinesque 1820) & Pistolgrip & $x$ & $x$ \\
\hline Fusconaia flava (Rafinesque 1820) & Wabash pigtoe & $x$ & $x$ \\
\hline Ptychobranchus fasciolaris (Rafinesque 1820) & Kidneyshell & & $x$ \\
\hline Pleurobema rubrim (Rafinesque 1820) & Pigtoe & & $x$ \\
\hline Obovaria subrotunda (Rafinesque 1820) & Round hickorynut & & $x$ \\
\hline Quadrula metanevra (Rafinesque 1820) & Monkeyface & & $x$ \\
\hline Ligumia recta (Lamarck 1819) & Black sandshell & & $x$ \\
\hline Truncilla donaciformis (I. Lea 1820) & Fawnsfoot & & $x$ \\
\hline
\end{tabular}




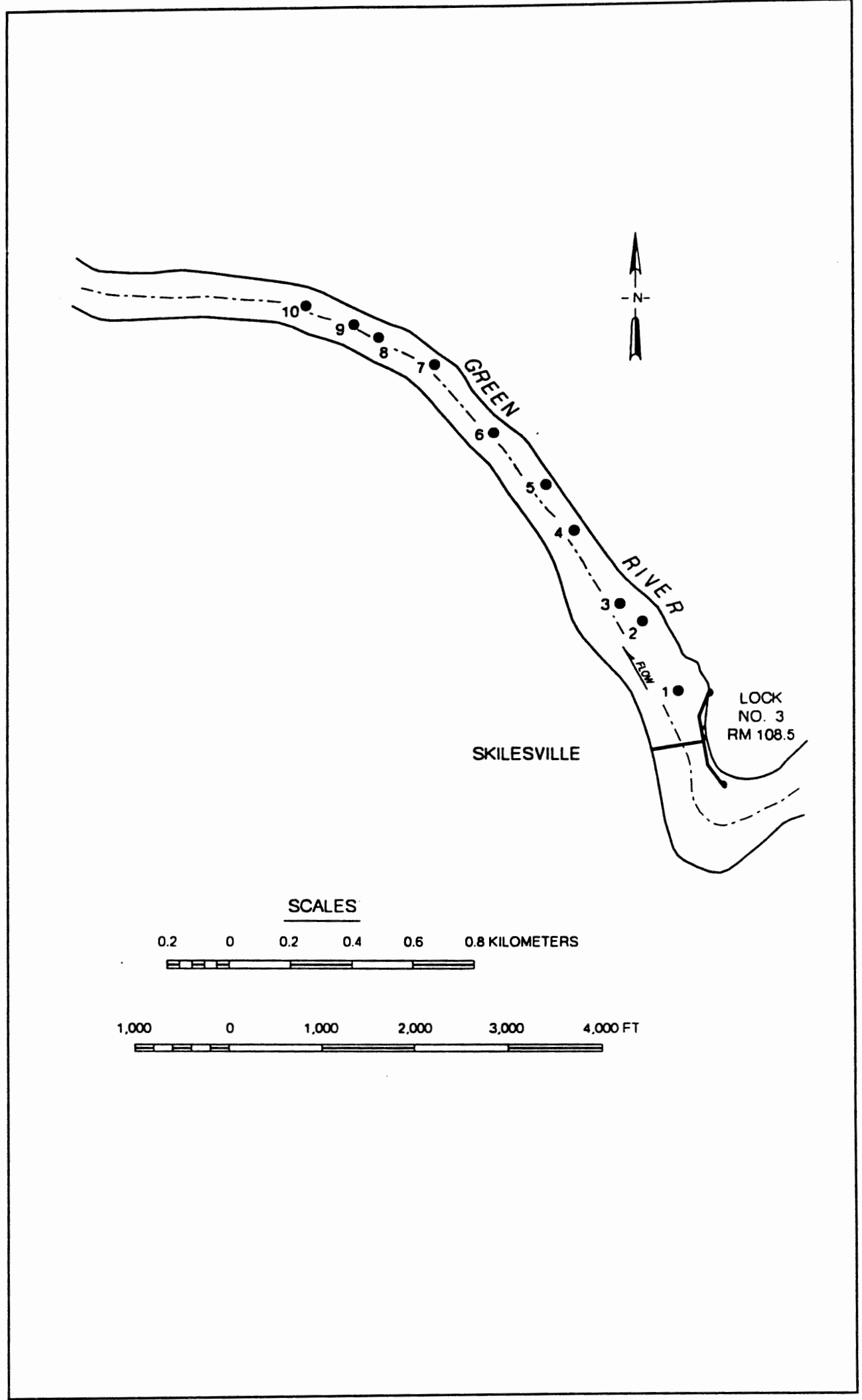

Figure 3. Location of sites downriver of Dam No. 3 where quantitative bivalve collections were made 


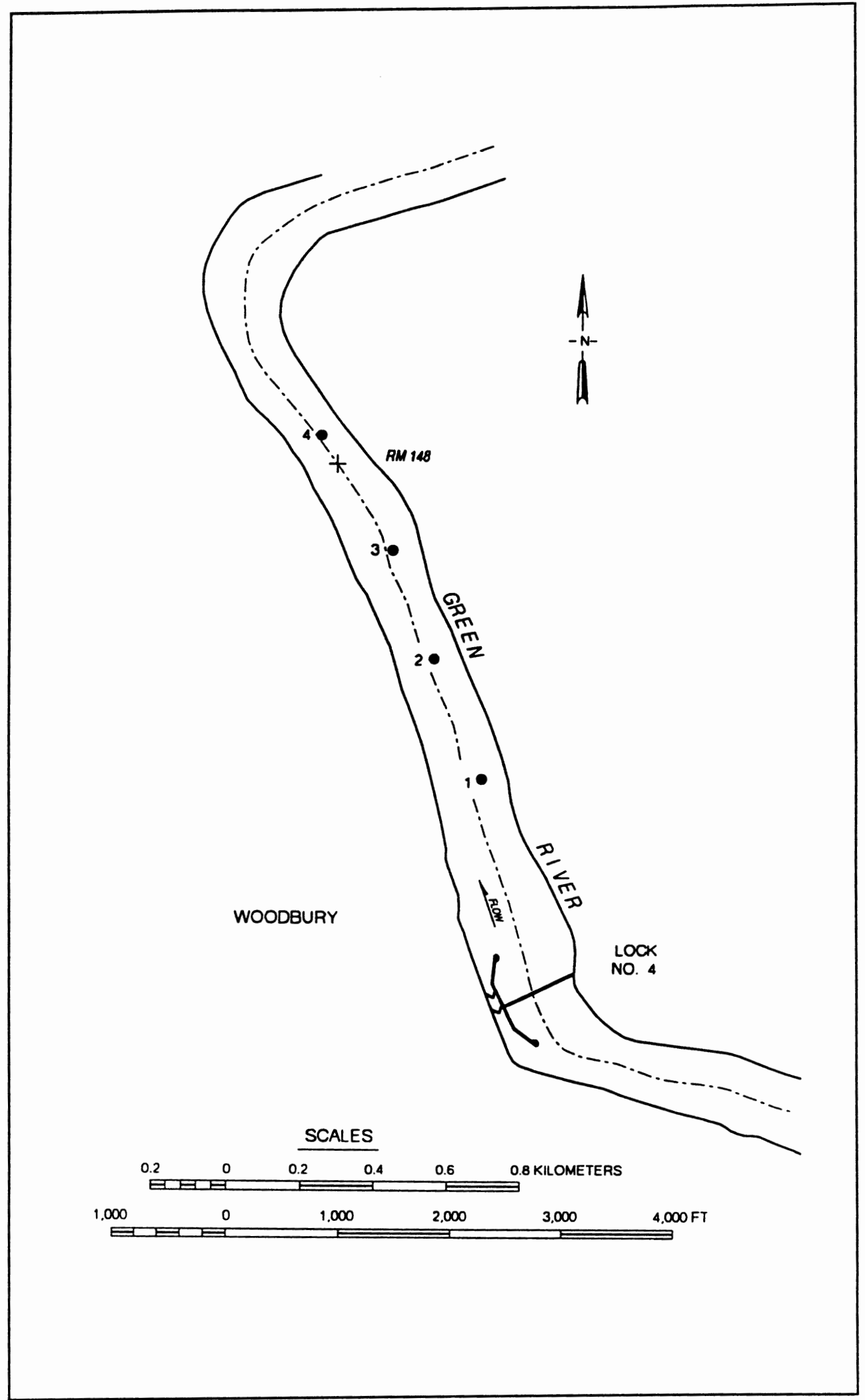

Figure 4. Location of sites downriver of Dam No. 4 where quantitative bivalve collections were made 
Data were analyzed using programs written in BASIC or SAS (Statistical Analytical System) on an IBM personal computer. Species effort curves and dominance-diversity curves were constructed from qualitative and quantitative data. These procedures are discussed in Green (1979); Hurlbert (1984); Magurran (1988); McNaughton and Wolf (1973); Isom and Gooch (1986); Kovalak, Dennis, and Bates (1986); Hughes (1986); and Miller and Payne (1988). 


\title{
3 Bivalve Community
}

\section{Results Obtained with Qualitative Sampling Methods}

\author{
Areas with low density \\ With the exception of beds at RM 101.5, 105.5, and 107.4 on the Green \\ River (discussed in more detail in the next section), mussel densities were \\ extremely low throughout most of the study areas on both rivers. These \\ sites are illustrated in Figure 2, and information on the number and spe- \\ cies of mussels collected at each appear in Appendix A (Tables A1 and \\ A2). A total of 98 individuals were collected, and 14 species were identi- \\ fied in these low-density areas (Appendix A). This fauna was dominated \\ by Megalonaias nervosa, Amblema plicata plicata, Quadrula quadrula, \\ and Lasmigona complanata. Live mussels were found at 15 of 20 sites on \\ the Green River and at 2 of 7 sites investigated on the Barren River.
}

\section{Areas with moderate density}

Three sites on the Green River had densities high enough for extensive qualitative sampling. These were located downriver of Dam No. 3 at RM 101.5, 105.5, and 107.4. Qualitative samples were not taken downriver of Dam No. 4 because the mussel bed was extremely small and densities were too low to support intensive sampling.

A total of 473 freshwater mussels were collected in 34 qualitative samples (nylon bags of mussels) at three sites downriver of Dam 3 (Table 2). Nineteen species were identified although the fauna was dominated by three thick-shelled species ( $A$. p. plicata, M. nervosa, and Elliptio crassidens) that together comprised 68.9 percent of the unionids. Seven species each comprised between 2 and 5 percent, and nine species each comprised less than 2 percent of the fauna. At two of the sites (RM 101.5 and RM 107.4), dominance values were low, less than 0.20 , and species diversity $\left(H^{\prime}\right)$ was more than 70-percent maximum possible diversity. At RM 105.0, dominance was moderately high, 0.40 (mainly because of the 


\begin{tabular}{|c|c|c|c|c|}
\hline \multirow[b]{2}{*}{ Species } & \multicolumn{3}{|c|}{ River Mile } & \multirow[b]{2}{*}{ Total } \\
\hline & 101.5 & 105.5 & 107.4 & \\
\hline A. p. plicata & 25.86 & 61.49 & 16.94 & 35.52 \\
\hline M. nervosa & 18.97 & 4.02 & 32.79 & 18.82 \\
\hline E. crassidens & 18.97 & 11.49 & 14.75 & 14.59 \\
\hline O. reflexa & 4.31 & 3.45 & 5.46 & 4.44 \\
\hline P. alatus & 5.17 & 5.75 & 2.19 & 4.23 \\
\hline L. complanata & 8.62 & 4.60 & 0.55 & 4.02 \\
\hline Q.p. pustulosa & 6.03 & 1.72 & 4.37 & 3.81 \\
\hline E. lineolata & 0.86 & 1.15 & 8.20 & 3.81 \\
\hline Q. quadrula & 0.86 & 4.02 & 2.73 & 2.75 \\
\hline P. cordatum & 1.72 & - & 4.92 & 2.33 \\
\hline E. dilatata & 0.86 & - & 2.19 & 1.06 \\
\hline Q. nodulata & 1.72 & 0.57 & 1.09 & 1.06 \\
\hline L. fragilis & 2.59 & 0.57 & - & 0.85 \\
\hline A. ligamentina & - & 0.57 & 1.09 & 0.63 \\
\hline A. confragosus & 2.59 & - & - & 0.63 \\
\hline T. truncata & - & 0.57 & 0.55 & 0.42 \\
\hline F. ebena & 0.86 & - & 0.55 & 0.42 \\
\hline T. verrucosa & - & - & 1.09 & 0.42 \\
\hline F. flava & - & - & 0.55 & 0.21 \\
\hline Total individuals & 116 & 174 & 183 & 473 \\
\hline Total species & 15 & 13 & 17 & 19 \\
\hline Species diversity & 2.14 & 1.47 & 2.12 & 2.08 \\
\hline $\begin{array}{l}\text { Theoretical } \\
\text { maximum } \\
\text { diversity }\end{array}$ & 2.71 & 2.86 & 2.83 & 2.94 \\
\hline Evenness & 0.79 & 0.57 & 0.75 & 0.71 \\
\hline Dominance & 0.15 & 0.40 & 0.17 & 0.19 \\
\hline
\end{tabular}


high percentage of $A$. p. plicata). No thin-shelled species (for example Anodonta spp. or Leptodea fragilis) were found at these sites.

Each of the three species that comprised more than 14 percent of the fauna were found in more than 75 percent of the qualitative samples (Table 3). A graphical depiction of percent abundance and percent occurrence of unionid species obtained in samples collected using qualitative methods appears in Figure 5. Percent abundance values span two orders of magnitude.

The relationship between cumulative number of individuals and cumulative number of species collected illustrates the difficulty of finding rare species. The relationship indicates that the number of new species taken per unit effort continually decreases with increasing cumulative effort. At these three sites, 15 of the 19 species ( 79 percent of the total) were identified after 116 of the 473 individuals (24.5 percent of the total) were collected. After 116 individuals were collected (Figure 6), approximately 100 more individuals had to be obtained to find a new species. It is unlikely that a large number of species were still at this bed and not represented in the sample of nearly 500 mussels. However, there is always the chance that a few additonal species could be taken with additional sampling.

\section{Results Obtained with Quantitative Sampling Methods}

\section{Bivalve density}

Ten quantitative samples were taken at each of 10 sites separated by intervals of 500 to $1,000 \mathrm{ft}$, beginning downriver of Dam 3 (Figure 3). Mussels were found at all sites except Site 1 that was within $800 \mathrm{ft}$ of the dam. Mean unionid density was $7.0,16.0$, and 6.0 individuals/sq $\mathrm{m}$ in the upper (Sites 2 and 3), center (Sites 4-7), and lower (Sites 8 and 9) sections of the bed (Figure 7). Mean unionid density was significantly higher $(p<0.05)$ in the center than at the upper and lower sections of the bed (Table 4). Densities were reduced at the upriver section of the bed because of higher current velocity and erosive conditions brought about by Dam No. 3. At the downriver section of the bed, densities were reduced because substratum consisted of less stable sand and gravel than existed in the center of the bed. Mean density of $C$. fluminea was low, 0.6, 2.2, and 0.0 individuals/sq $\mathrm{m}$ in the upper, center, and lower sections of this bed.

Mean bivalve density was less in the bed downriver of Dam No. 4 than in the bed downriver of Dam No. 3 (Figure 7, Table 4). Mean densities of $C$. fluminea were more than double those of the Unionidae at the lower section of this bed. Densities of $C$. fluminea and Unionidae increased gradually moving downriver from Dam No. 4. Mean density of unionids was not significantly different among sites $(p>0.05)$. At this bed 


\begin{tabular}{|c|c|c|c|c|}
\hline \multirow[b]{2}{*}{ Species } & \multicolumn{3}{|c|}{ River Mile } & \multirow[b]{2}{*}{ Total } \\
\hline & 101.5 & 105.5 & 107.4 & \\
\hline A. p. plicata & 80.00 & 100.00 & 83.33 & 88.24 \\
\hline E. crassidens & 80.00 & 75.00 & 91.67 & 82.35 \\
\hline M. nervosa & 90.00 & 41.67 & 100.00 & 76.47 \\
\hline O. reflexa & 40.00 & 33.33 & 58.33 & 44.12 \\
\hline P. alatus & 40.00 & 58.33 & 25.00 & 41.18 \\
\hline L. complanata & 60.00 & 41.67 & 8.33 & 35.29 \\
\hline Q.p.pustulosa & 50.00 & 16.67 & 33.33 & 32.35 \\
\hline E. lineolata & 10.00 & 16.67 & 58.33 & 29.41 \\
\hline Q. quadrula & 10.00 & 33.33 & 33.33 & 26.47 \\
\hline P. cordatum & 10.00 & - & 41.67 & 17.65 \\
\hline E. dilatata & 10.00 & - & 25.00 & 11.76 \\
\hline Q. nodulata & 20.00 & 8.33 & 8.33 & 11.76 \\
\hline A. ligamentina & - & 8.33 & 16.67 & 8.82 \\
\hline L. fragilis & 20.00 & 8.33 & - & 8.82 \\
\hline T. truncata & - & 8.33 & 8.33 & 5.88 \\
\hline F. ebena & 10.00 & - & 8.33 & 5.88 \\
\hline A. confragosus & 20.00 & - & - & 5.88 \\
\hline F. flava & - & - & 8.33 & 2.94 \\
\hline T. verrucosa & - & - & 8.33 & 2.94 \\
\hline Total samples & 10 & 12 & 12 & 34 \\
\hline
\end{tabular}




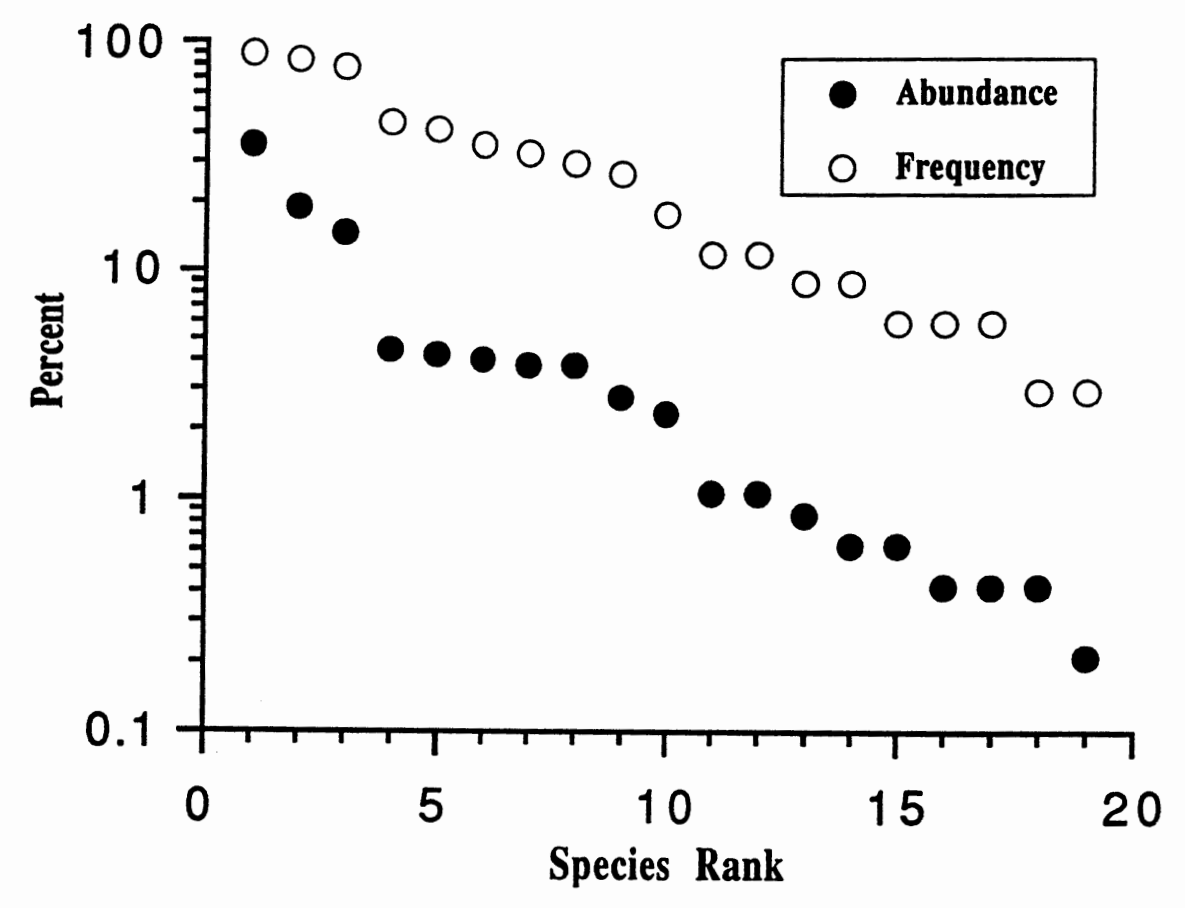

Figure 5. Percent abundance and percent occurrence for mussels collected at RM 101.5, 105.5, and 107.4 in the Green River, using qualitative methods, 1992

downriver of Dam No. 4, mean density of $C$. fluminea and unionids increased gradually and then abruptly declined (moving downriver) when the bed ended.

\section{Community characteristics}

A total of 24 species of bivalves, including the Asian clam, $C$. fluminea, was collected using quantitative methods immediately downriver of Dam No. 3 (Table 5). Four species (M. nervosa, Pleurobema cordatum, E. crassidens, and Corbicula fluminea) were numerically dominant, and each comprised more than 10 percent of the fauna. Community parameters such as species diversity and evidence of recent recruitment were calculated on the community both with and without $C$. fluminea (Table 5). For the most part, the community parameters (species diversity, evenness, and dominance) are affected little by excluding the Asian clam. All of the recruitment in the upper portion of the bed was from $C$.

Fluminea. In the center of the bed, more than 50 percent of the bivalve recruitment was caused by $C$. Fluminea. In the lower section of the bed, $C$. Fluminia was not found. 


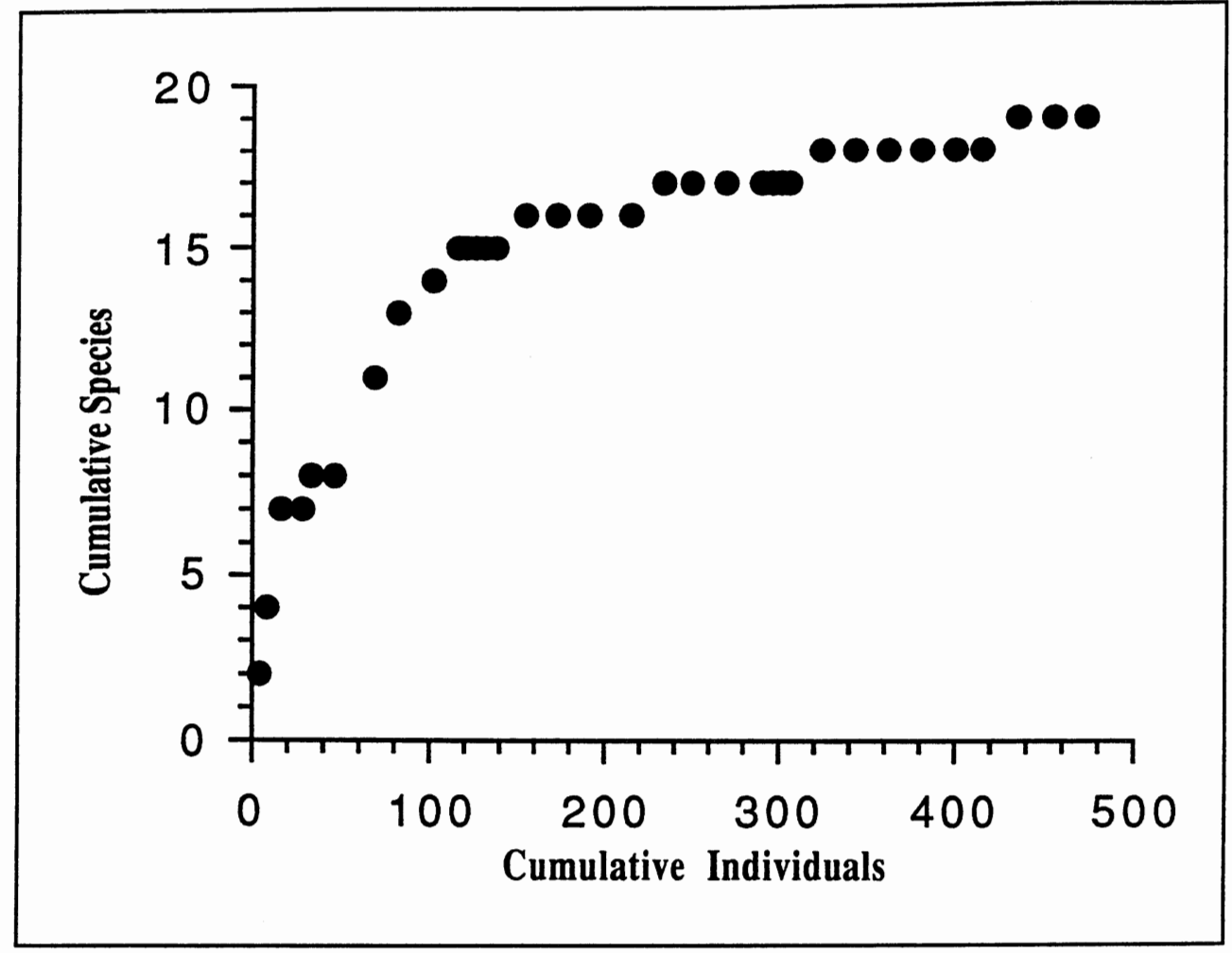

Figure 6. Relationship between cumulative individuals and cumulative species for mussels collected at RM 101.5, 105.5, and 107.4 in the Green River, using qualitative methods, 1992

Megalonaias nervosa was found in 75 percent of the quantitative samples collected using quantitative methods at the upper end of the bed (Table 6). The total percent occurrence for $M$. nervosa at all nine sites was 42 percent. Nine species were collected in greater than 13 percent of the quadrats, whereas 15 species were found in less than 10 percent of the quadrats.

Percentage abundance of $M$. nervosa decreased moving downriver, whereas percentage abundance of $P$. cordatum and $E$. crassidens exhibited the reverse trend (Figure 8). Evidence of recent bivalve recruitment (individuals and species of bivalves less than $30-\mathrm{mm}$ total shell) was greatest in the center of the bed (Figure 9). Species were less evenly distributed among the assemblage at the upper and lower section of the bed, whereas the center of the bed had a more even distribution of species (Figure 10).

A total of 15 species of bivalves, including C. fluminea, and 79 individuals were collected in $\mathbf{4 0}$ quantitative samples at four sites downriver of Dam No. 4 (Table 7). Corbicula fluminea numerically dominated and comprised 58 percent of the fauna and was found in 45 percent of all quadrats (Table 8). Evenness was comparatively low (0.497) at Site 4, the farthest downriver, reflecting the high dominance of Asian clams. Evenness 


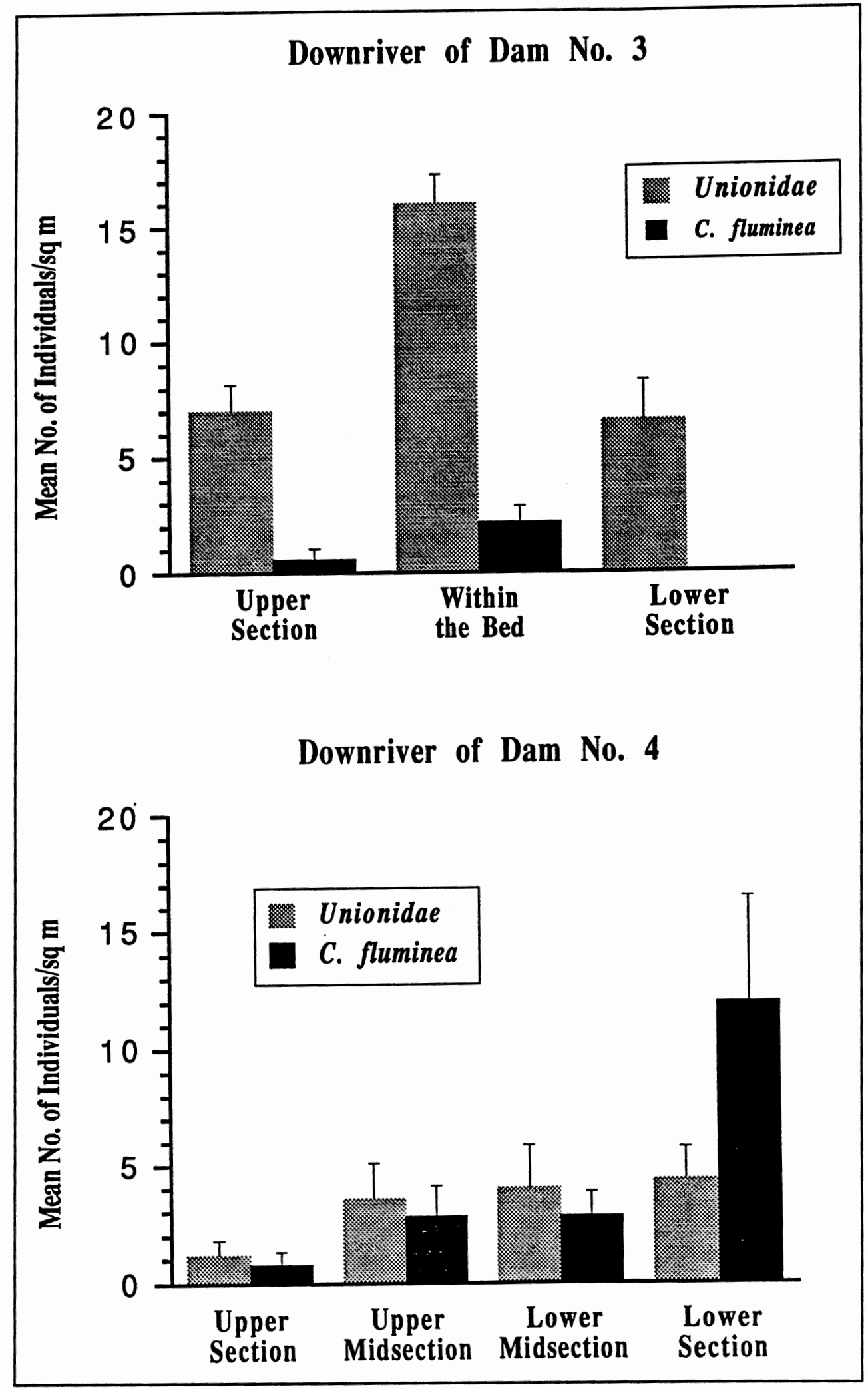

Figure 7. Total mean density for unionids and Corbicula fluminea immediately downrivar of Dam Nos. 3 and 4 in the Green River, 1992 


\section{Table 4}

Mean Density and Standard Error of the Mean (SE) for

Unionidae and Corbicula fluminea Collected Immediately Downriver of Dam Nos. 3 and 4, Green River, Kentucky, 1992

\begin{tabular}{|c|c|c|c|c|c|}
\hline \multirow[b]{2}{*}{ Location } & \multicolumn{2}{|c|}{ Unionidae } & \multicolumn{2}{|c|}{ C. fluminea } & \multirow{2}{*}{$\begin{array}{l}\text { Number of } \\
\text { Quadrats }\end{array}$} \\
\hline & Mean & SE & Mean & SE & \\
\hline \multicolumn{6}{|c|}{ Downriver of Dam No. 3} \\
\hline $\begin{array}{l}\text { Upper } \\
\text { section of } \\
\text { bed }\end{array}$ & $7.00 \mathrm{~b}$ & 1.16 & $0.60 a$ & 0.44 & 20 \\
\hline Center of bed & $16.00 \mathrm{a}$ & 1.27 & $2.16 \mathrm{a}$ & 0.70 & 50 \\
\hline $\begin{array}{l}\text { Lower } \\
\text { section of } \\
\text { bed }\end{array}$ & $6.60 \mathrm{~b}$ & 1.72 & $-a$ & - & 20 \\
\hline \multicolumn{6}{|c|}{ Downriver of Dam No. 4} \\
\hline $\begin{array}{l}\text { Upper } \\
\text { section of } \\
\text { bed }\end{array}$ & $1.20 \mathrm{a}$ & 0.61 & $0.80 b$ & 0.53 & 10 \\
\hline $\begin{array}{l}\text { Upper } \\
\text { midsection } \\
\text { of bed }\end{array}$ & $3.60 \mathrm{a}$ & 1.51 & $2.80 \mathrm{~b}$ & 1.33 & 10 \\
\hline $\begin{array}{l}\text { Lower } \\
\text { midsection } \\
\text { of bed }\end{array}$ & $4.00 \mathrm{a}$ & 1.88 & $2.80 \mathrm{~b}$ & 1.04 & 10 \\
\hline $\begin{array}{l}\text { Lower } \\
\text { section of } \\
\text { bed }\end{array}$ & $4.40 \mathrm{a}$ & 1.39 & $12.00 \mathrm{a}$ & 4.49 & 10 \\
\hline
\end{tabular}




\section{Table 5 \\ Percent Species Abundance of Bivalves Collected in Quantitative Samples Immediately Downriver of Dam No. 3, Green River, Kentucky, 1992 (Approximate River Mile $=\mathbf{1 0 8 . 0}$ )}

\begin{tabular}{|c|c|c|c|c|}
\hline Species & $\begin{array}{l}\text { Upper Section } \\
\text { of Bed }\end{array}$ & Center of Bed & $\begin{array}{l}\text { Lower Section } \\
\text { of Bed }\end{array}$ & Total \\
\hline M. nervosa & 55.26 & 11.45 & 3.03 & 16.11 \\
\hline P. cordatum & 2.63 & 15.42 & 24.24 & 14.77 \\
\hline E. crassidens & 7.89 & 8.81 & 33.33 & 11.41 \\
\hline C. fluminea & 7.89 & 11.89 & - & 10.07 \\
\hline Q.p. pustulosa & 5.26 & 10.13 & - & 8.39 \\
\hline O. reflexa & 2.63 & 8.81 & 6.06 & 7.72 \\
\hline E. lineolata & 5.26 & 6.61 & 6.06 & 6.38 \\
\hline A. p. plicata & 5.26 & 4.85 & 12.12 & 5.70 \\
\hline E. dilatata & 2.63 & 6.61 & - & 5.37 \\
\hline P. fasciolaris & 5.26 & 3.08 & - & 3.02 \\
\hline Q. quadrula & - & 2.64 & - & 2.01 \\
\hline P. rubrim & - & 1.76 & - & 1.34 \\
\hline F. ebena & - & 1.76 & - & 1.34 \\
\hline A. ligamentina & - & 1.32 & - & 1.01 \\
\hline Q. nodulata & - & 1.32 & - & 1.01 \\
\hline O. subrotunda & - & 0.44 & 3.03 & 0.67 \\
\hline$T$. truncata & - & 0.88 & - & 0.67 \\
\hline P. alatus & - & 0.88 & - & 0.67 \\
\hline Q. metanevra & - & - & 6.06 & 0.67 \\
\hline L. recta & - & - & 3.03 & 0.34 \\
\hline F. flava & - & - & 3.03 & 0.34 \\
\hline T. verrucosa & - & 0.44 & - & 0.34 \\
\hline T. donaciformis & - & 0.44 & - & 0.34 \\
\hline L. fragilis & - & 0.44 & - & 0.30 \\
\hline
\end{tabular}




\begin{tabular}{|c|c|c|c|c|}
\hline \multicolumn{5}{|l|}{ Table 5 (Concluded) } \\
\hline Species & $\begin{array}{l}\text { Upper Section } \\
\text { of Bed }\end{array}$ & Center of Bed & $\begin{array}{l}\text { Lower Section } \\
\text { of Bed }\end{array}$ & Total \\
\hline \multicolumn{5}{|c|}{ Including C. fluminea } \\
\hline Total individuals & 38 & 227 & 33 & 298 \\
\hline Total species & 10 & 21 & 10 & 24 \\
\hline Species diversity & 1.63 & 2.59 & 1.90 & 2.58 \\
\hline Maximum diversity & 2.30 & 3.04 & 2.30 & 3.18 \\
\hline Evenness & 0.71 & 0.85 & 0.82 & 0.81 \\
\hline Dominance & 0.31 & 0.09 & 0.17 & 0.09 \\
\hline$\%$ Individuals $<30 \mathrm{~mm} \mathrm{SL}$ & 7.89 & 14.97 & 3.03 & 12.75 \\
\hline$\%$ Species < $30 \mathrm{~mm} \mathrm{SL}$ & 10.00 & 28.57 & 10.00 & 25.00 \\
\hline \multicolumn{5}{|c|}{ Excluding $C$. fluminea } \\
\hline Total individuals & 35 & 200 & 33 & 268 \\
\hline Total species & 9 & 20 & 10 & 23 \\
\hline Species diversity & 1.48 & 2.53 & 1.90 & 2.50 \\
\hline Maximum diversity & 2.20 & 3.00 & 2.30 & 3.13 \\
\hline Evenness & 0.67 & 0.84 & 0.82 & 0.80 \\
\hline Dominance & 0.36 & 0.09 & 0.17 & 0.10 \\
\hline$\%$ Individuals $<30 \mathrm{~mm} \mathrm{SL}$ & 0.00 & 4.00 & 3.03 & 3.35 \\
\hline \%Species < $30 \mathrm{~mm} \mathrm{SL}$ & 00.00 & 25.00 & 10.00 & 21.74 \\
\hline
\end{tabular}




\begin{tabular}{|c|c|c|c|c|}
\hline \multicolumn{5}{|c|}{$\begin{array}{l}\text { Table } 6 \\
\text { Percent Occurrence of Bivalves Collected in Quantitative Samples } \\
\text { Immediately Downriver of Dam No. 3, Green River, Kentucky, } 1992 \\
\text { (Approximate River Mile }=108.0 \text { ) }\end{array}$} \\
\hline Species & $\begin{array}{l}\text { Upper Section } \\
\text { of Bed }\end{array}$ & Center of Bed & $\begin{array}{l}\text { Lower Section } \\
\text { of Bed }\end{array}$ & Total \\
\hline M. nervosa & 75.00 & 44.00 & 5.00 & 42.22 \\
\hline P. cordatum & 5.00 & 44.00 & 30.00 & 32.22 \\
\hline E. crassidens & 10.00 & 30.00 & 30.00 & 25.56 \\
\hline 0. reflexa & 5.00 & 36.00 & 10.00 & 23.33 \\
\hline Q. p. pustulosa & 10.00 & 36.00 & - & 22.22 \\
\hline E. lineolata & 10.00 & 30.00 & 10.00 & 21.11 \\
\hline A. p. plicata & 10.00 & 18.00 & 20.00 & 16.67 \\
\hline E. dilatata & 5.00 & 24.00 & - & 14.44 \\
\hline C. fluminea & 10.00 & 20.00 & - & 13.33 \\
\hline P. fasciolaris & 10.00 & 12.00 & - & 8.89 \\
\hline Q. quadrula & - & 12.00 & - & 6.67 \\
\hline F. ebena & - & 8.00 & - & 4.44 \\
\hline P. rubrim & - & 6.00 & - & 3.33 \\
\hline Q. nodulata & - & 6.00 & - & 3.33 \\
\hline A. ligamentina & - & 6.00 & - & 3.33 \\
\hline O. subrotunda & - & 2.00 & 5.00 & 2.22 \\
\hline T. truncata & - & 4.00 & - & 2.22 \\
\hline Q. metanevra & - & - & 10.00 & 2.22 \\
\hline P. alatus & - & 4.00 & - & 2.22 \\
\hline T. verrucosa & - & 2.00 & - & 1.11 \\
\hline T. donaciformis & - & 2.00 & - & 1.11 \\
\hline F. flava & - & - & 5.00 & 1.11 \\
\hline L. recta & - & - & 5.00 & 1.11 \\
\hline L. fragilis & - & 2.00 & - & 1.11 \\
\hline Total samples & 20 & 50 & 20 & 90 \\
\hline
\end{tabular}




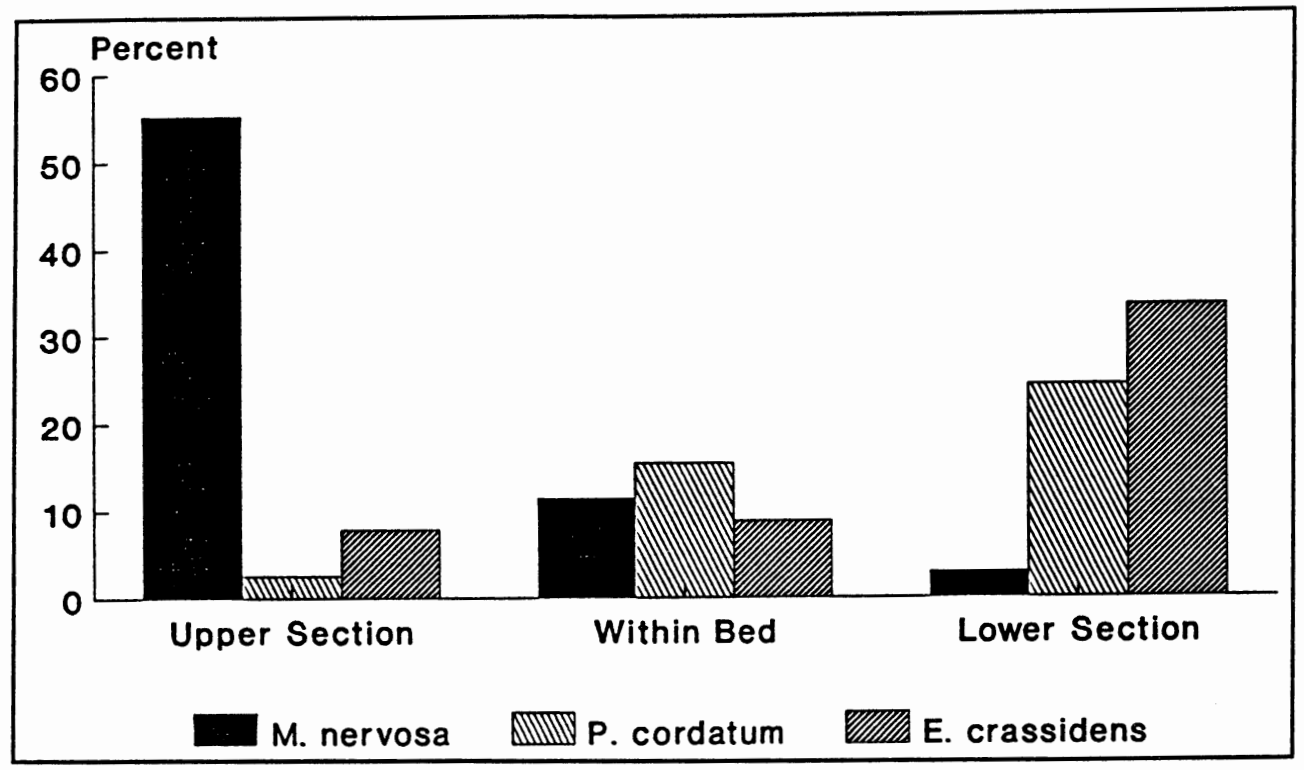

Figure 8. Percent abundance of Megalonaias nervosa, Pleurobema cordatum, and Elliptio crassidens at a mussel bed immediately downriver of Dam No. 3 in the Green River, based on results of quantitative sampling

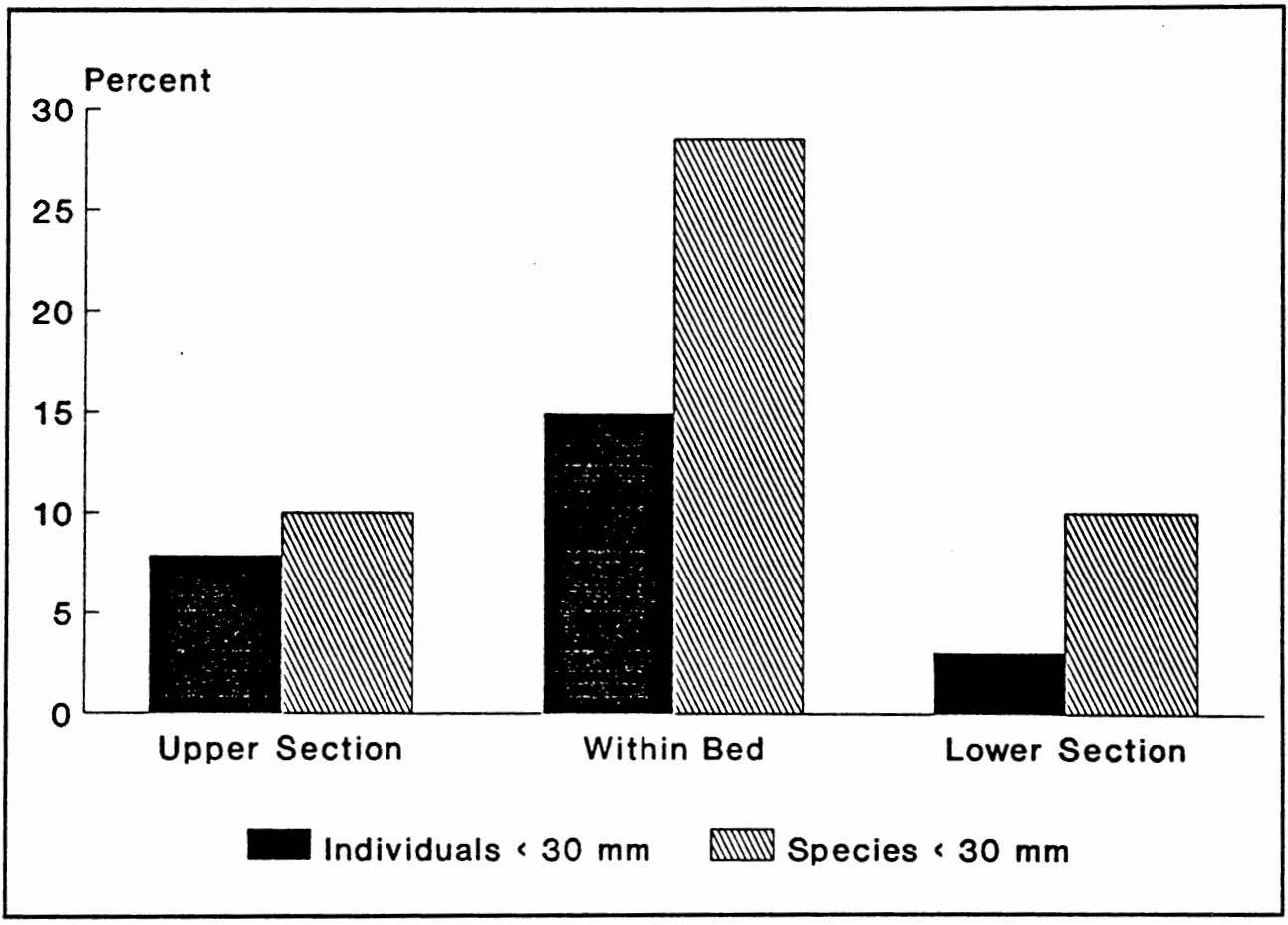

Figure 9. Percent of individuals and species (all bivalues included) less than $30-\mathrm{mm}$ total shell length at a mussel bed immediately downriver of Dam No. 3 in the Green River, 1992 

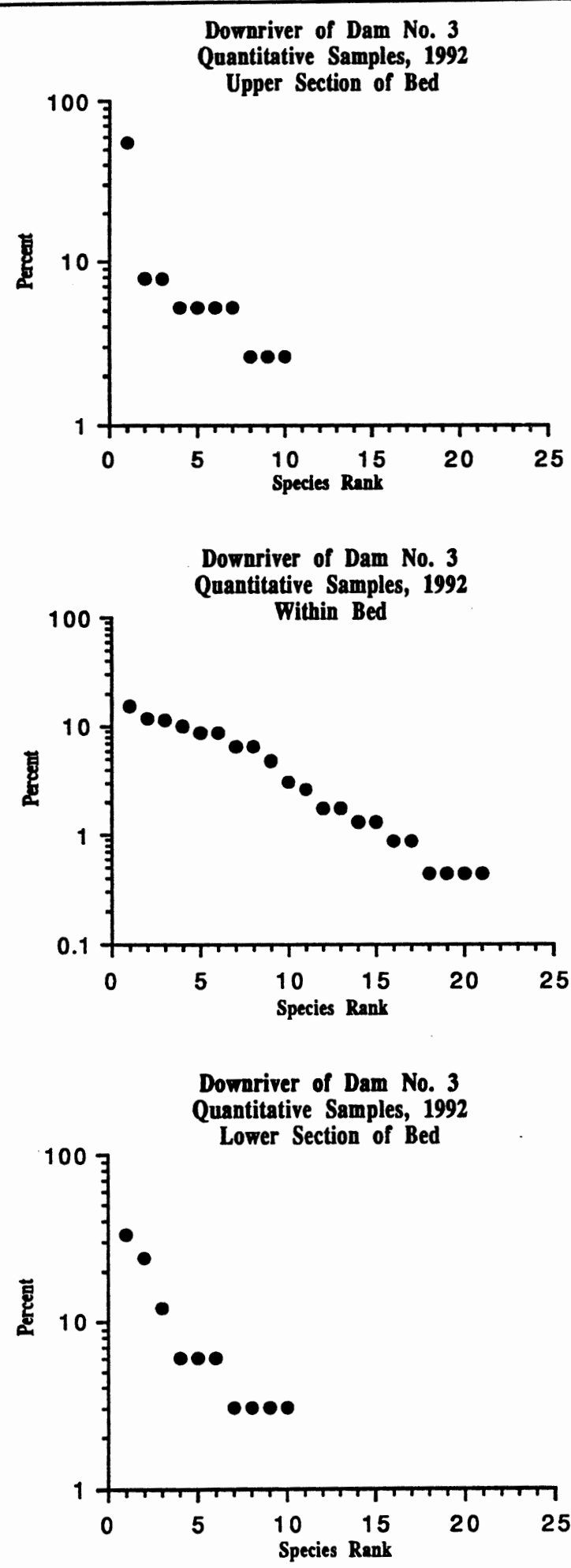

Figure 10. Relationship between species rank and percent abundance (for all bivalues) of individuals for the upper, midsection, and lower portion of a mussel bed immediately downriver of Dam No. 3 in the Green River, 1992 


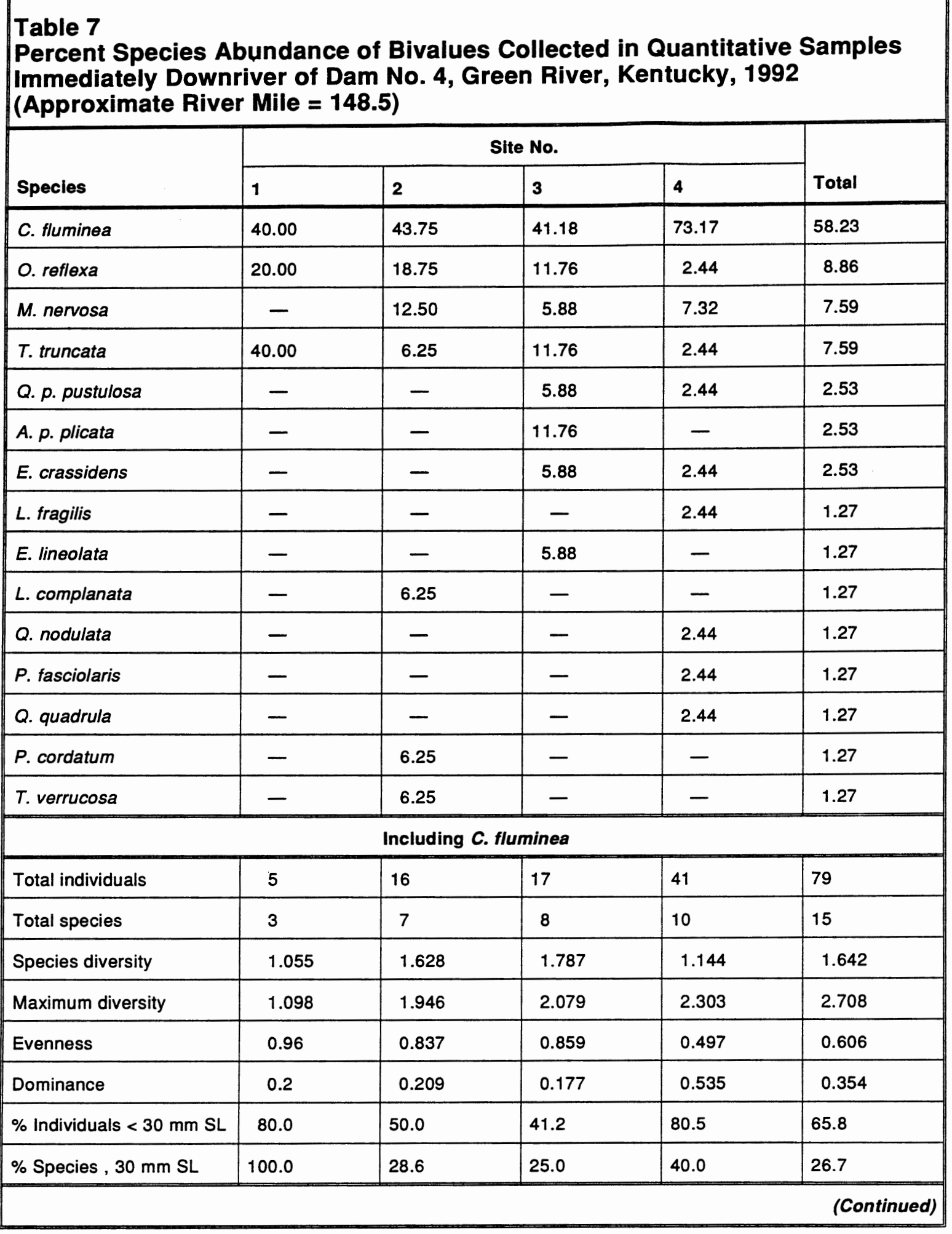




\begin{tabular}{|l|l|l|l|l|l|}
\hline \multirow{2}{*}{ Table 7 (Concluded) } & \multicolumn{3}{c|}{ Site No. } & \multirow{2}{*}{ Total } \\
\cline { 2 - 6 } & 1 & 2 & 3 & 4 \\
\hline \multicolumn{5}{|c|}{ Excluding C. fluminea } \\
\hline Total individuals & 3 & 9 & 10 & 11 & 33 \\
\hline Total species & 2 & 6 & 7 & 9 & 14 \\
\hline Species diversity & 0.64 & 1.68 & 1.89 & 2.10 & 2.30 \\
\hline Maximum diversity & 0.69 & 1.79 & 1.95 & 2.20 & 2.64 \\
\hline Evenness & 0.92 & 0.94 & 0.97 & 0.95 & 0.87 \\
\hline Dominance & 0.33 & 0.11 & 0.07 & 0.05 & 0.10 \\
\hline \% Individuals < 30 mm SL & 66.67 & 11.11 & 10.00 & 00.0 & 21.21 \\
\hline \% Species < 30 mm SL & 100.00 & 16.67 & 14.28 & 00.0 & 21.43 \\
\hline Note: Maximum diversities are calculated or theoretical. & & & \\
\hline
\end{tabular}

Table 8

Percent Frequency of Occurrence of Bivalves Collected in Quantitative Samples Immediately Downriver of Dam No. 4, Green River, Kentucky, 1992 (Approximate River Mile $=148.5$ )

\begin{tabular}{|c|c|c|c|c|c|}
\hline \multirow[b]{2}{*}{ Species } & \multicolumn{4}{|c|}{ Site No. } & \multirow[b]{2}{*}{ Total } \\
\hline & 1 & 2 & 3 & 4 & \\
\hline C. fluminea & 20.00 & 40.00 & 50.00 & 70.00 & 45.00 \\
\hline T. truncata & 20.00 & 10.00 & 20.00 & 10.00 & 15.00 \\
\hline M. nervosa & - & 20.00 & 10.00 & 30.00 & 15.00 \\
\hline D. reflexa & 10.00 & 10.00 & 20.00 & 10.00 & 12.50 \\
\hline Q.p. pustulosa & - & - & 10.00 & 10.00 & 5.00 \\
\hline A. p. plicata & - & - & 20.00 & - & 5.00 \\
\hline E. crassidens & - & - & 10.00 & 10.00 & 5.00 \\
\hline Q. nodulata & - & - & - & 10.00 & 2.50 \\
\hline Q. quadrula & - & - & - & 10.00 & 2.50 \\
\hline L. complanata & - & 10.00 & - & - & 2.50 \\
\hline$P$. fasciolaris & - & 一 & - & 10.00 & 2.50 \\
\hline T. verrucosa & - & 10.00 & - & - & 2.50 \\
\hline P. cordatum & - & 10.00 & 一 & - & 2.50 \\
\hline E. lineolata & 一 & - & 10.00 & - & 2.50 \\
\hline L. fragilis & - & 一 & 一 & 10.00 & 2.50 \\
\hline Total samples & 10 & 10 & 10 & 10 & 40 \\
\hline
\end{tabular}


was comparatively higher, and dominance comparatively less, at Sites 1-3 located farther upriver, due to reduced percent abundance of $C$. fluminea.

The percentage of bivalves less than $30-\mathrm{mm}$ total shell length for all four sites in the bed downriver of Dam No. 4 (65.8 percent, Table 7) was substantially greater than the percentage less than $30 \mathrm{~mm}$ downriver of Dam No. 3 (12.75 percent, Table 5), due mainly to the presence of greater numbers of small-sized $C$. fluminea. If $C$. fluminea is eliminated from this analysis, the unionids at the bed downriver of Dam No. 4 still exhibited greater evidence of recent recruitment ( 21.2 percent) than did the bed downriver of Dam No. 3 (3.3 percent) (see Tables 5 and 7). The percentage of unionid species (bivalves exclusive of $C$. fluminea) was approximately the same (about 21.5 percent) at both beds (Tables 5 and 7 ).

The more even distribution of bivalue species within the assemblage at the bed located downriver of Dam No. 3 contrasts with the comparatively uneven distribution of species within the community at the bed downriver of Dam No. 4 (Figure 11, Tables 5 and 7). In addition, percent occurrence of species in the quantitative samples was more evenly distributed within the assemblage in the bed immediately downriver of Dam No. 3 than at Dam No. 4.

Downriver of Dam No. 3, 298 individuals and 24 species of bivalves were collected in 90 quantitative samples (Table 5). Downriver of Dam 4, 79 individuals and 15 species of bivalves were taken in 40 quantitative samples (Table 7). Species were identified at about the same rate at both beds (Figure 12). After 78 individuals had been collected below Dam No. 4, 15 species had been identified. After 100 individuals had been collected downriver of Dam No. 3, 15 species had been identified.

The species list for mussels collected using quantitative methods (results obtained from collections downriver of Dam Nos. 3 and 4 combined), contained six species not found in the qualitative collection (Table 1). The six species taken in the total substratum sample downriver of Dam No. 3 that were not found in the qualitative samples were Ptychobranchus fasciolaris, Pleurobema rubrim, Obovaria subrotunda, Quadrula metanevra, Ligumia recta, and Truncilla donaciformis.

Truncilla donaciformis is a small-sized mussel even as an adult and was probably missed by divers when searching the substratum by feel. The other five species are medium-sized and are usually collected with qualitative methods. Because they were very uncommon, they were likely missed by the divers. Two species, Lasmigona complanata and Arcidens confragosus, were found in qualitative but not quantitative samples.

\section{Size demography of dominant populations downriver of Dam No. 3}

Shell length frequency histograms were prepared for population samples of 20 or more individuals. Due to the low density of mussels in the 


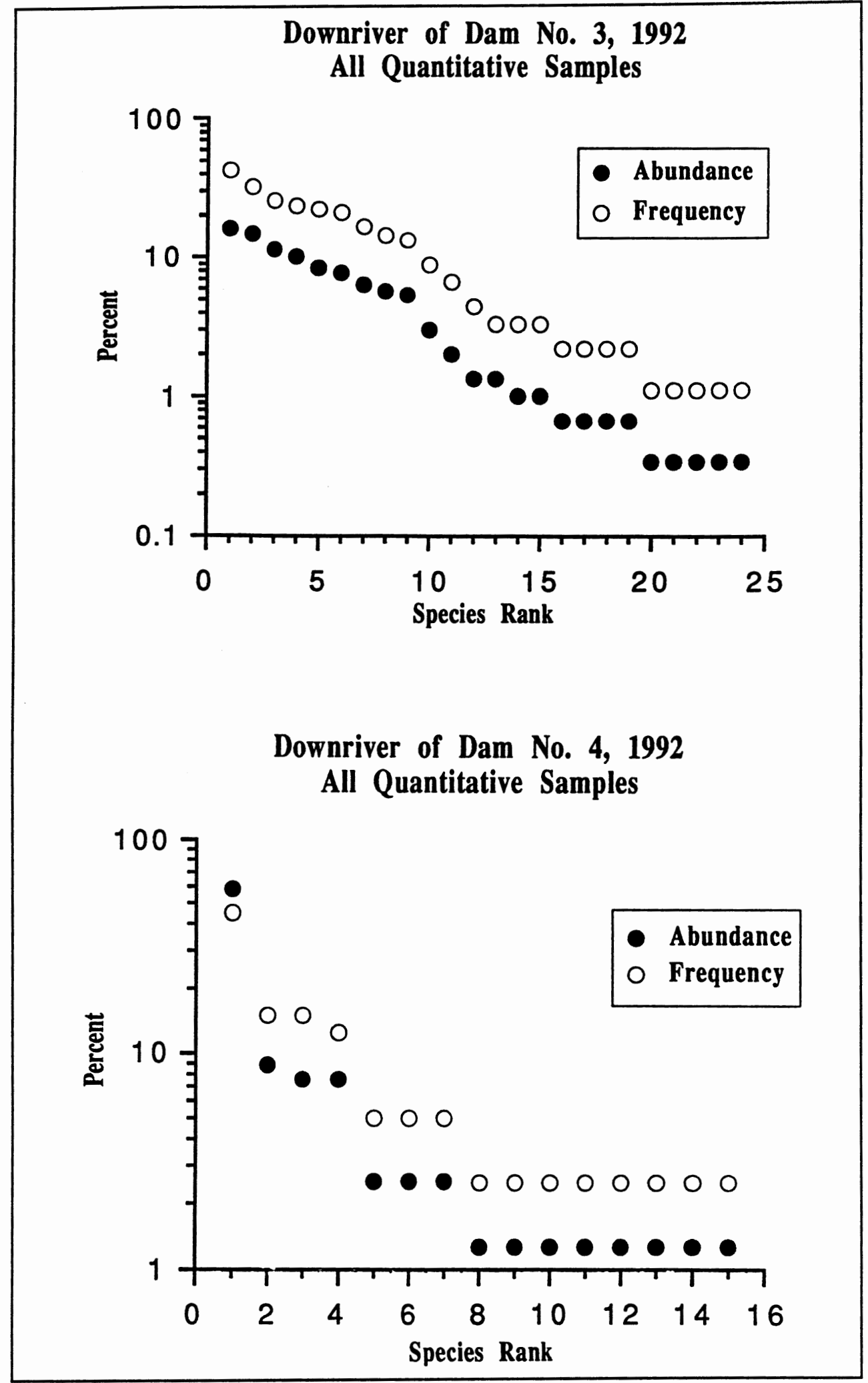

Figure 11. Percent abundance and percent occurrence for bivalves collected immediately downriver of Dam No. 3 (top) and Dam No. 4 (bottom) in the Green River, 1992 


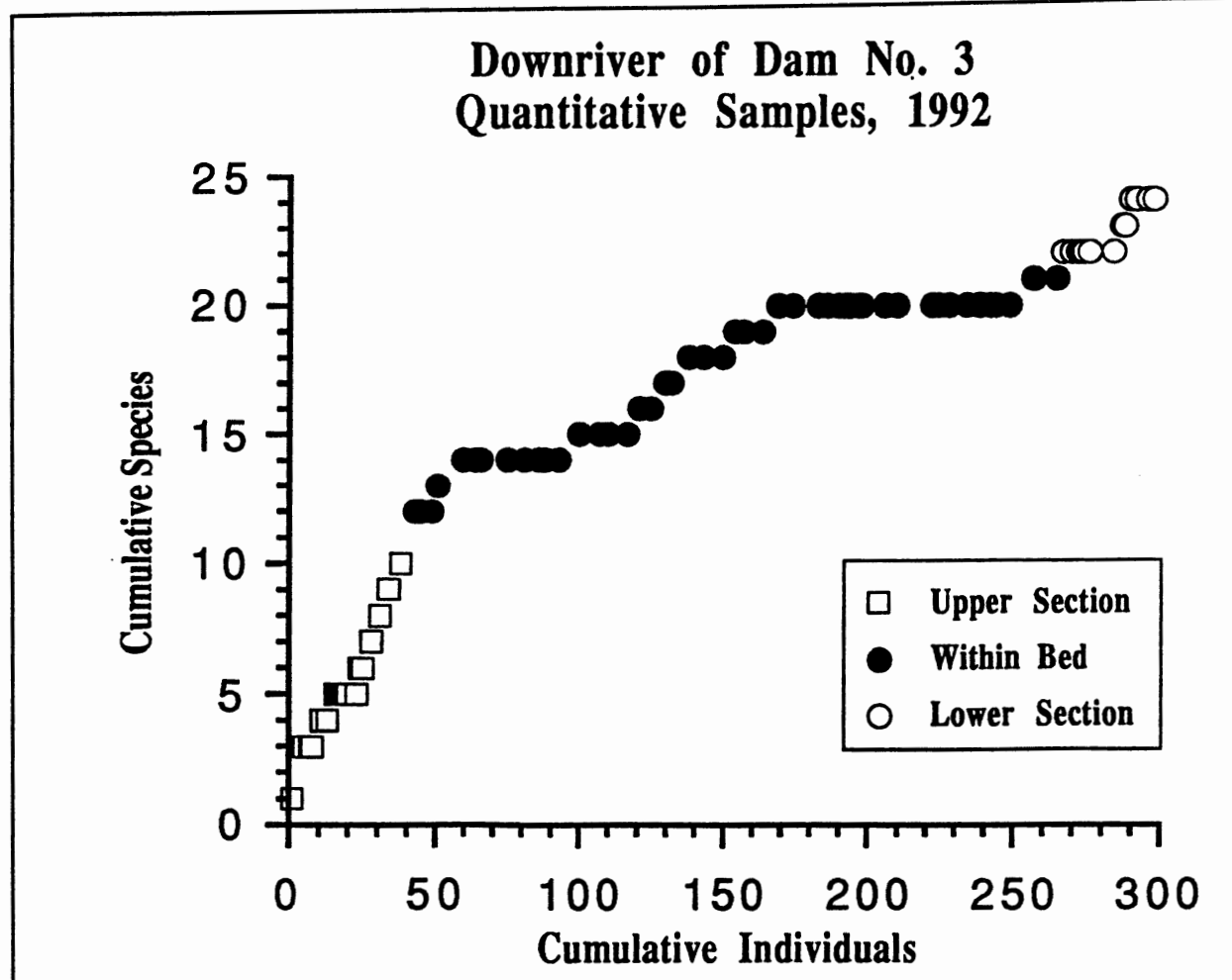

Downriver of Dam No. 4

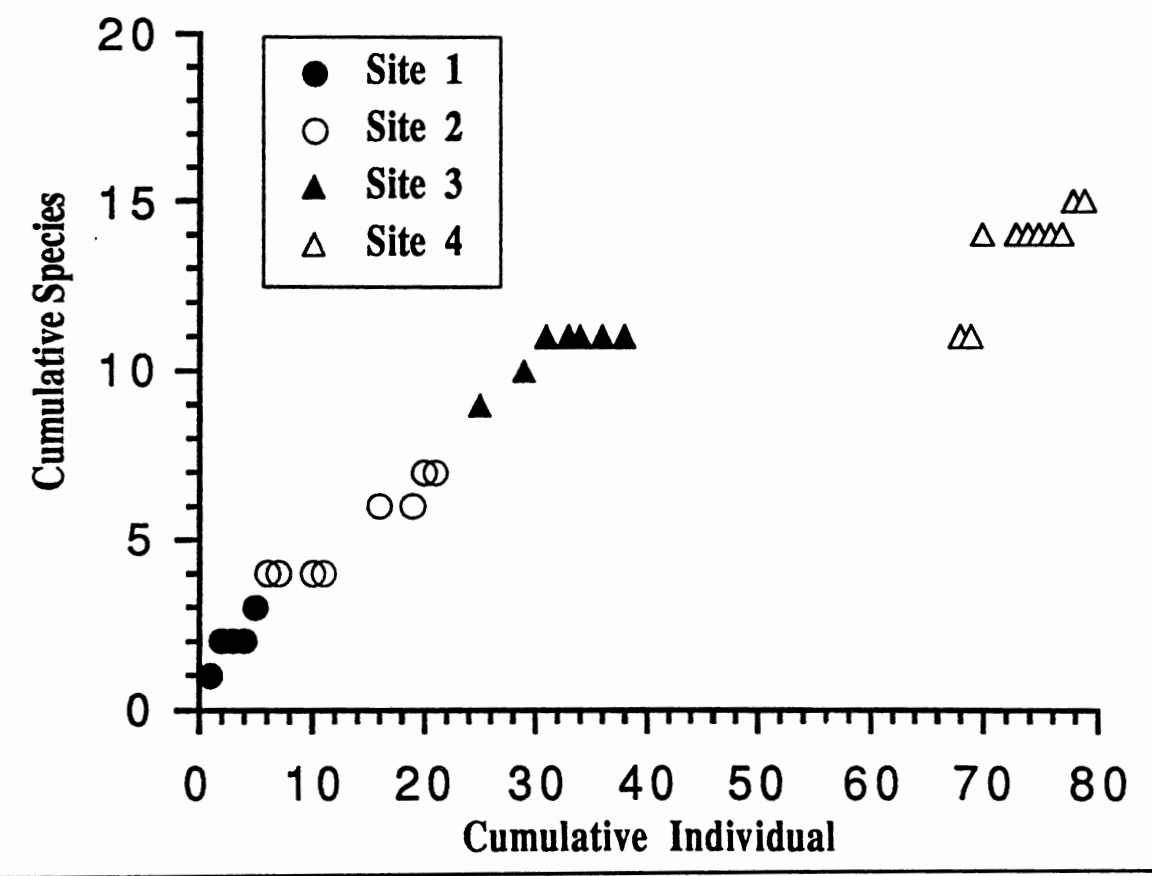

Figure 12. Relationship between cumulative individuals and cumulative species for bivalves collected immediately downriver of Dam No. 3 (top) and Dam No. 4 (bottom) in the Green River, 1992 
quantitative samples, only three populations were collected in sufficient number to allow inspection of size demography. These species were $M$. nervosa $(n=47), P$. cordatum $(n=22)$, and $C$. fluminea $(n=22)$. The population of $M$. nervosa was composed almost entirely of large and relatively old mussels, with 44 of 47 individuals collected ranging from 13 to $16.5 \mathrm{~cm}$ in length (Figure 13). The largest specimen measured $18 \mathrm{~cm}$ in length and approached the maximum recorded size for this species. Not a single individual less than $10 \mathrm{~cm}$ in length was collected, indicating poor recruitment to this population. In populations with reasonably strong recent recruitment, it is not unusual to collect several $M$. nervosa less than $10 \mathrm{~cm}$ in length. This usually includes some individuals representing recruits of the last 1 to 3 years that are 1 to $4 \mathrm{~cm}$ long (Miller and Payne 1992). Likewise, the $P$. cordatum population was represented almost entirely by relatively large, old mussels (Figure 14). All but one of the 22 individuals taken in quantitative samples measured between 7 and $9 \mathrm{~cm}$ in length. The smallest individual collected was approximately $5 \mathrm{~cm}$ in length, and no recent recruits (i.e., individuals less than $4 \mathrm{~cm}$ in length) were found. In populations with substantial recent recruitment, a considerable number of individuals less than $5 \mathrm{~cm}$ in length are expected, including individuals less than $3 \mathrm{~cm}$ in length (Miller and Payne 1991).

The population of $C$. fluminea was represented mostly by a small cohort ranging in length from 4 to $14 \mathrm{~mm}$ (Figure 15). Sixteen of the twentytwo individuals in this population sample were in that length range. The remaining individuals ranged upward in length to a maximum of $30 \mathrm{~mm}$. In a large $(n>100)$ sample of a dense $C$. fluminea population with complex age structure, 3 to 5 cohorts are typically observed with the length of the largest cohort averaging 25 to $35 \mathrm{~mm}$ (Payne et al. 1989). Thus, the full expected size range of $C$. fluminea was represented in this small sample from the Green River population. However, this population was heavily dominated by the cohort of small, recent (either spring or summer, 1992) recruits. 


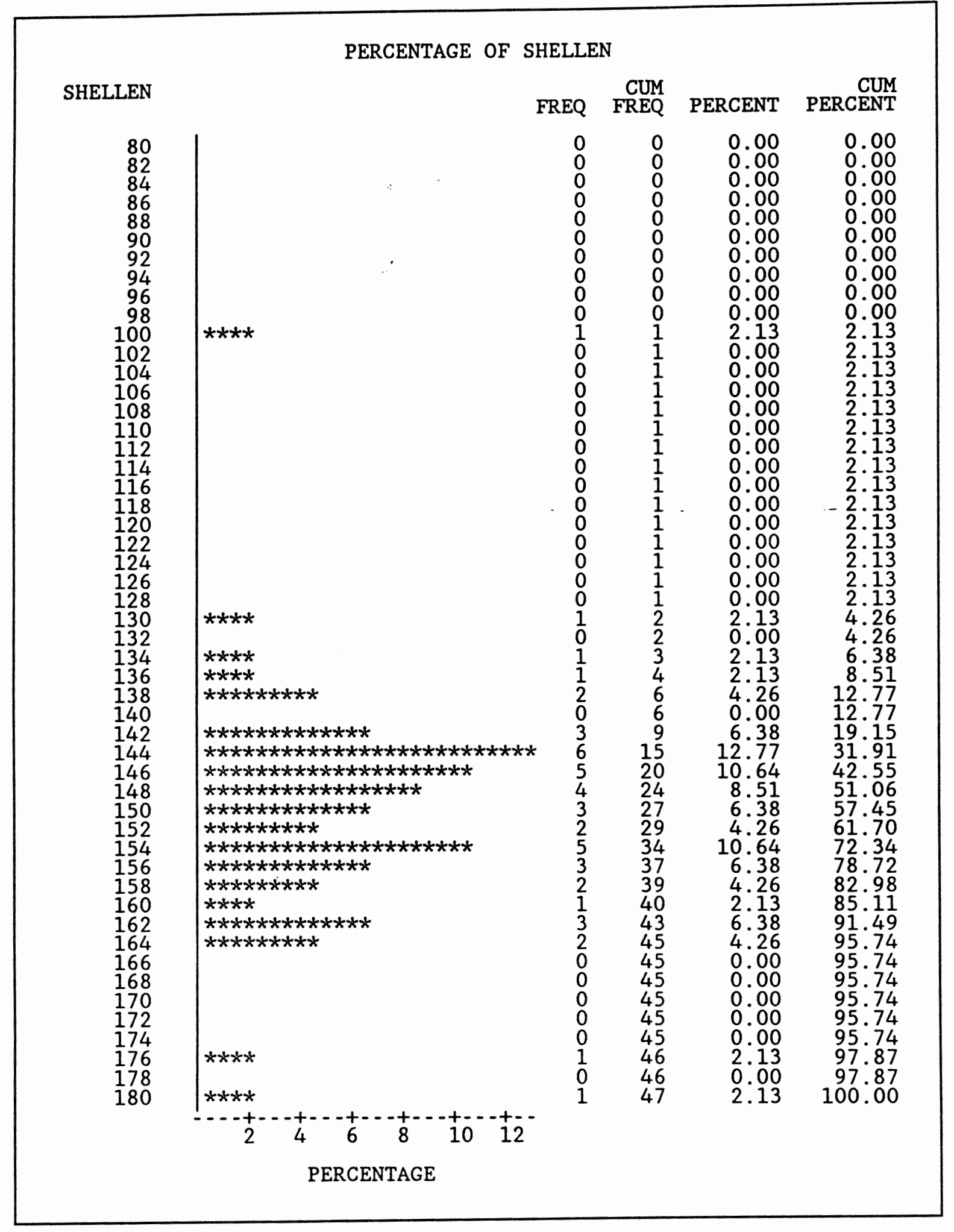

Figure 13. Length-frequency histogram for Megalonaias nervosa collected at a mussel bed immediately downriver of Dam No. 3 in the Green River, 1992, using quantitative methods 
PERCENTAGE OF SHELLEN

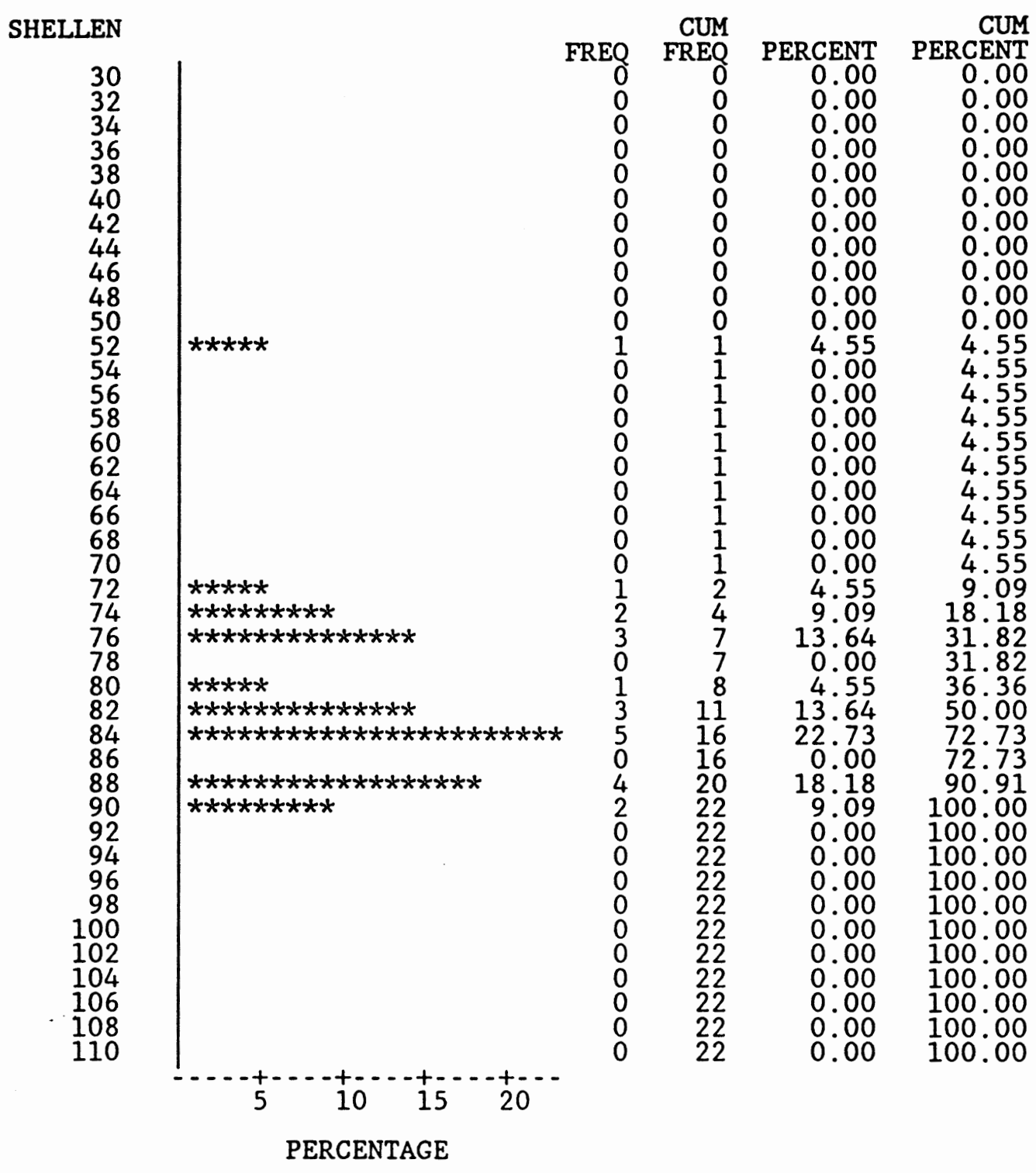

Figure 14. Length-frequency histogram for Pleurobema cordatum collected at a mussel bed immediately downriver of Dam No. 3 in the Green River, 1992, using quantitative methods 


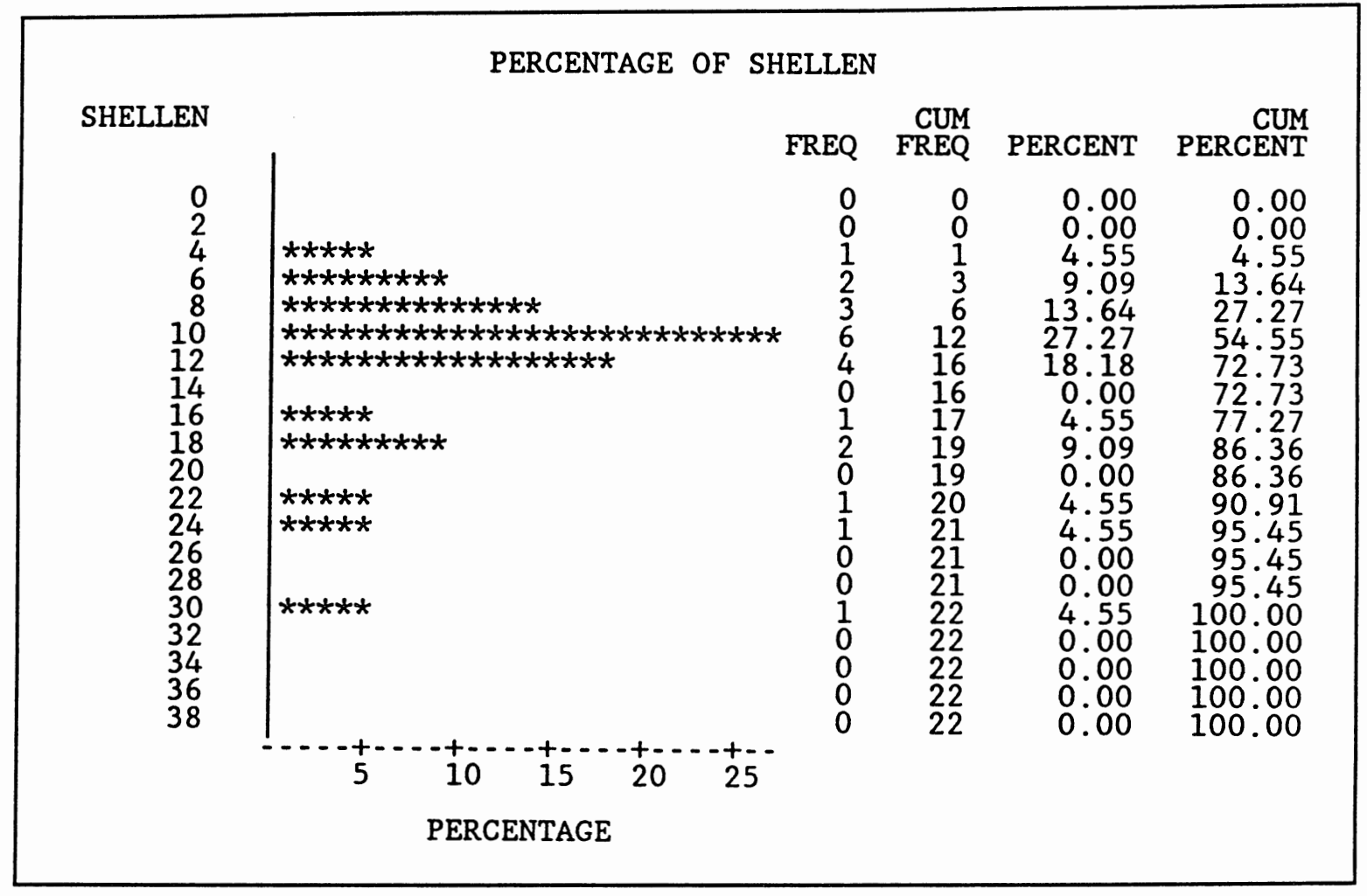

Figure 15. Length-frequency histogram for Corbicula fluminea collected at a mussel bed immediately downriver of Dam No. 3 in the Green River, 1992, using quantitative methods 


\section{Discussion}

\section{Comparison with Results of Study by Williams (1969)}

During the summer and early fall of 1968 , Williams (1969) collected mussels in three sections of the Green River. Area I included the upper reach downriver to the eastern boundary of Mammoth Cave National Park. The second area extended from Mammoth Cave National Park downriver to Dam No. 4. Area III extended from Dam No. 4 to the mouth of the Green River, a distance of 149 miles. Sampling in this lower reach, which included the section studied during this survey, was done mainly by brail and diving. The objectives of Williams' study were to determine the extent of mussel beds, species composition, population density, harvest, recruitment, and reproduction for 306 miles of the Green River and portions of the Tennessee and Ohio Rivers in Kentucky.

Williams (1969) reported that areas impounded by dams, except reaches immediately below dams, had few living mussels. He estimated that densities ranged from 0.0 to 1.5 individuals/sq yd ( 0.0 to 1.8 individuals/sq $\mathrm{m})$ in these areas. Species composition consisted mainly of $M$. nervosa and Amblema costata (=plicata plicata). The results of the present survey, conducted 24 years later, provided similar results as those described by Williams. At the majority of the sites that WES personnel surveyed in the Green and Barren River, densities were judged too low for detailed sampling. Intensive qualitative collecting methods were used at only 3 of 27 sites examined during the preliminary survey.

Williams (1969) reported high quality mussel beds immediately downriver of Dam Nos. 3 and 4. He collected 130 individuals and 19 species downriver of Dam No. 3, and WES researchers collected 268 individuals and identified 23 species of unionids (Table 5). Williams (1969) collected 89 individuals downriver of Dam No. 4 and identified 19 species, and WES personnel collected 33 individuals and identified 14 species of unionids (Table 7). Based on qualitative and quantitative sampling, WES personnel collected a total of 741 individuals and identified 25 species downriver of Dam No. 3 (the sum of columns 3 and 5 in Table 9). 


\begin{tabular}{|c|c|c|c|c|c|c|c|c|}
\hline \multirow[b]{3}{*}{ Specles } & \multirow{2}{*}{\multicolumn{2}{|c|}{ Brail and Diving ${ }^{1}$}} & \multicolumn{6}{|c|}{ Results of WES Survey } \\
\hline & & & \multicolumn{2}{|c|}{ Quantitative Downriver of } & \multicolumn{2}{|c|}{ Qualitative } & \multicolumn{2}{|c|}{ Total } \\
\hline & \begin{tabular}{|l}
$\begin{array}{l}\text { Total } \\
\text { Number }\end{array}$ \\
\end{tabular} & \begin{tabular}{|l}
$\begin{array}{l}\text { Percent } \\
\text { Abundance }\end{array}$ \\
\end{tabular} & Dam 3 & Dam 4 & $\begin{array}{l}\text { Downriver } \\
\text { of Dam } 3\end{array}$ & $\begin{array}{l}\text { Low Density } \\
\text { Sites } \\
\end{array}$ & Number & Percent \\
\hline Megalonaias nervosa & 304 & 36.02 & 48 & 6 & 89 & 34 & 177 & 20.30 \\
\hline Amblema plicata & 208 & 24.64 & 17 & 2 & 168 & 12 & 199 & 22.82 \\
\hline Elliptio crassidens & 106 & 12.56 & 34 & 2 & 69 & 3 & 108 & 12.38 \\
\hline Pleurobema cordatum & 52 & 6.16 & 44 & 1 & 11 & 3 & 59 & 6.77 \\
\hline Ptychobranchus fasciolaris & 25 & 2.96 & 9 & 1 & - & - & 10 & 1.15 \\
\hline Fusconaia undata & 14 & 1.66 & - & - & - & - & - & - \\
\hline Quadrula pustulosa & 14 & 1.66 & 25 & 2 & 18 & 7 & 52 & 5.96 \\
\hline Fusconaia ebena & 13 & 1.54 & 4 & - & 2 & - & 6 & 0.69 \\
\hline Potamilus alatus & 13 & 1.54 & 2 & - & 20 & 4 & 26 & 2.98 \\
\hline Elliptio dilatata & 12 & 1.42 & 16 & - & 5 & - & 21 & 2.41 \\
\hline Ellipsaria lineolata & 12 & 1.42 & 19 & 1 & 18 & 1 & 39 & 4.48 \\
\hline Lampsilis ovata & 12 & 1.42 & - & - & - & - & - & - \\
\hline Quadrula quadrula & 10 & 1.18 & 6 & 1 & 13 & 11 & 31 & 3.55 \\
\hline Plourobema coccineum & 8 & 0.95 & - & - & - & - & - & - \\
\hline Pleurobema plenum & 7 & 0.83 & - & - & - & - & - & - \\
\hline Ligumia recta & 5 & 0.59 & 1 & - & - & - & 1 & 0.12 \\
\hline Obliquaria refiexa & 5 & 0.59 & 23 & 7 & 21 & 3 & 54 & 6.19 \\
\hline Quadrula nodulata & 5 & 0.59 & 3 & 1 & 5 & 2 & 11 & 1.26 \\
\hline Tritogonia verrucosa & 4 & 0.47 & 1 & 1 & 2 & 3 & 7 & 0.80 \\
\hline Obovaria subrotunda & 3 & 0.36 & 2 & - & - & - & 2 & 0.23 \\
\hline Actinonaias ligamentina & 2 & 0.24 & 3 & - & 3 & - & 6 & 0.69 \\
\hline Cyclonaias tuberculata & 2 & 0.24 & - & - & - & - & - & - \\
\hline Obovaria olivaria & 2 & 0.24 & - & - & - & - & - & - \\
\hline Fusconaia subrotunda & 1 & 0.12 & - & - & - & - & - & - \\
\hline Lampsilis cariosa & 1 & 0.12 & - & - & - & - & - & - \\
\hline Lasmigona costata & 1 & 0.12 & - & - & - & - & - & - \\
\hline Lampsilis luteola & 1 & 0.12 & - & - & - & - & - & - \\
\hline Obovaria retusa & 1 & 0.12 & - & - & - & - & - & - \\
\hline Truncilla donaciformis & 1 & 0.12 & 1 & - & - & - & 1 & 0.12 \\
\hline Lasmigona complanata & - & - & - & 1 & 19 & 11 & 31 & 3.56 \\
\hline Arcidens confragosus & - & - & - & - & 3 & - & 3 & 0.34 \\
\hline \multirow[t]{2}{*}{ Leptodea fragilis } & - & $1-$ & 1 & 1 & 4 & - & 6 & 0.69 \\
\hline & & & & & & & & Continued \\
\hline \multicolumn{9}{|l|}{ owniver of } \\
\hline
\end{tabular}




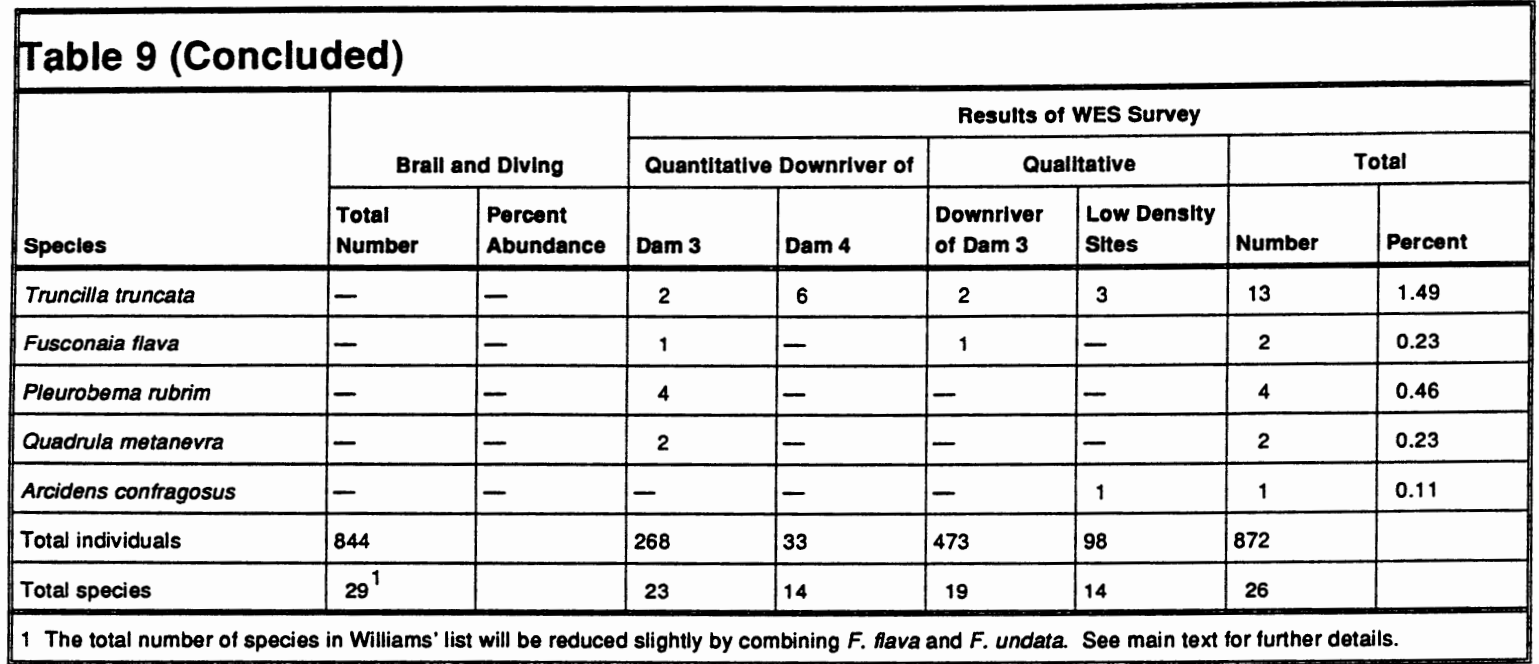

In the river reach designated as Area III, Williams (1969) collected 844 mussels and identified 29 species (Table 9). As indicated by Isom (1974), Lampsilis cariosa was not identified correctly and was probably Lampsilis cardium. Lampsilis luteola was probably Lampsilis radiata. In addition, Fusconaia undata and Fusconaia flava should be considered a single species (L. flava). ${ }^{1}$ These changes have only a minor effect on Williams' list. The list compiled by Williams includes 28 species (because of the two Fusconaia were combined) rather than 29.

When results obtained by quantitative and qualitative methods used in the present study were combined, 872 individuals were found, and 26 species of unionids were identified. WES personnel found some species that were probably present but not collected by Williams (such as L. fragilis and Truncilla truncata). Some species collected by Williams (Cyclonaias tuberculata and Obovaria olivaria) composed less than 1 percent of his collection. It should not be surprising for any collector to miss uncommon species. However, when results of both surveys are compared, it is apparent that species richness and basic community structure, i.e., dominance of thick-shelled species such as A. p. plicata and $M$. nervosa, has remained virtually unchanged since 1968 .

Extremely low unionid densities immediately downriver of Dam No. 4 were found in this study. Density was less than 4.0 individuals/sq $\mathrm{m}$, whereas density downriver of Dam No. 3 ranged from 7 to 16 individuals/ $\mathrm{sq} \mathrm{m}$. Divers reported that the substratum downriver of Dam No. 4 was composed mostly of sand with little firm gravel. When this dam failed in 1965 , it is possible that current patterns and substratum stability were altered immediately downriver. These changes could have taken place

1

Personal communication, Dr. Art Bogan, 14 December 1992, Sewell, NJ. 
gradually and might not have been noticed when Williams conducted his survey.

\section{Population and Community Dynamics}

\section{Community composition}

The mussel assemblage in the reach of the Green River surveyed consisted almost entirely of thick-shelled species. No federally listed endangered species were collected (U.S. Fish and Wildlife Service 1991). The fauna was dominated by $A$. p. plicata, M. nervosa, Quadrula spp, with lesser numbers of Elliptio spp. Thin- and moderately thick-shelled species (Potamilus alatus and Anodonta spp.) were either uncommon or absent (see Table 9). Within their range, these thin-shelled species are commonly collected in fine-grained substratum (Murray and Leonard 1962, Parmalee 1967, Starrett 1971). The majority of the WES sampling was concentrated in habitats that usually do not support these thin-shelled species.

\section{Species richness}

Total species richness in the study reach is similar to that found in other medium- to large-size rivers. In the lower Ohio River near Olmsted, IL, 23 species of mussels were collected (Payne and Miller 1989). In the upper Mississippi River, Miller et al. (1990) collected over 15,000 bivalves in 667 qualitative samples at 58 locations and identified 34 species. However, total species richness at any one site was usually between 15 and 25. Large rivers usually support higher number of species than smaller rivers. Miller, Payne, and Hartfield (1992) reported 13 species of mussels in the Sunflower River, and 15 species in the Big Black River (Payne, unpublished information) in central Mississippi. Channel widths on both of these rivers were about half those of the Green River in the area surveyed by WES personnel in 1992 ..

\section{Relative species abundance}

Evenness, a measure of the distribution of species within a community, can range from near 1 (evenly distributed) to near zero (strongly dominated by few species). Based on qualitative and quantitative samples, evenness was 0.71 and 0.80 , respectively, downriver of Dam No. 3 (Tables 5 and 7). These high values indicated that the community was not strongly dominated by one or two species. At RM 18.6 in the lower Tennessee River, Way, Miller, and Payne (1989) reported that evenness was 0.392 at a site where Fusconaia ebena comprised 71 percent of the unionid community. 


\section{Density}

In comparison with other large-river mussel beds, the range in unionid density (6.0 to 16.0 individuals/sq $\mathrm{m}$ in the bed downriver of Dam No. 3) is low. At an inshore and offshore site in the lower Tennessee River at RM 18.6 on the left descending bank sampled in 1986 (32 quantitative samples were collected at each), total mussel density was 187.7 and 79.7 individuals/sq $\mathrm{m}$, respectively (Way, Miller, and Payne 1989). In a survey of the upper Mississippi River, Miller et al. (1990) reported that total mussel density ranged from 5.2 to 333.2 individuals/sq $\mathrm{m}$ at 16 sites (10 quantitative samples were taken at each). At half of the sites, total density was greater than 50 individuals/sq $\mathrm{m}$, and at four sites it was greater than 100 individuals/sq $\mathrm{m}$.

\section{Population demography}

Abundant unionid populations sampled in the present study had a much higher percentage of large individuals than did populations in the late 1960s (Williams 1969). William's study (in his Area III) (1969) indicated that approximately 80 percent of the $P$. cordatum population consisted of individuals 50 to $70 \mathrm{~mm}$ long, with only 20 percent of the population being larger than $70 \mathrm{~mm}$. This contrasts with the results of the present study, in which 95 percent of the $P$. cordatum population was larger than $70 \mathrm{~mm}$. The maximum length recorded by Williams was approximately $80 \mathrm{~mm}$, and the maximum length found in this survey was $90 \mathrm{~mm}$. Comparison of results of the present study with that of William's yielded a similar contrast for M. nervosa. In his Area III of the Green River, Williams reported that approximately 50 percent of the $M$. nervosa population was composed of individuals $>125 \mathrm{~mm}$ long (maximum $\mathrm{SL}=150 \mathrm{~mm}$ ); the remaining 50 percent of the population ranged in size from 50 to $125 \mathrm{~mm}$. Results of the present study indicated that in the $M$. nervosa population, 98 percent of the individuals were greater than $125 \mathrm{~mm}$ long, with a maximum size of $180 \mathrm{~mm}$.

\section{Concluding Comments}

When Williams (1969) surveyed the Green River in 1968, he reported that the lower river reach was heavily used by commercial towboats. Commercial traffic had used the lower river for over 100 years; locks and dams were built in the early 1800 s. In the 24 years between completion of surveys by Williams and WES personnel, the reach immediately downriver of Dam No. 3 has been virtually free of commercial vessels. In addition, the river appears to be relatively free of point and nonpoint pollution. Isom (1974) reported that effects of seepage or overland flow from oil wells were not found in the river. 
The results of this survey indicate that moderately dense mussel beds can be found downriver of Dar No. 3. This bed is characterized by moderately high species richness, species diversity, and evenness. When results of this survey are compared with results of the previous survey (Williams 1969), it is apparent that the bed downriver of Dam No. 3 has changed little over the past 24 years. A possible exception could be the mussel bed downriver of Dam No. 4, which WES personnel found to be localized and of moderate-to-low quality. It appears that breaching of Dam No. 4 changed habitat downriver and this affected the Unionidae. Although Williams did not provide detailed data that can be used for comparisons, it appears that conditions downriver of Dam No. 3 were unaffected by breaching of this dam. 


\section{References}

Academy of Natural Sciences of Philadelphia. (1983). "Aquatic baseline studies of the Green River, Martin Creek and Richmond Slough 19811982," for the International Coal Refining Company, Allantown, PA.

Burch, J. B. (1975). Freshwater Unionacean clams (Mollusca: Pelecypoda) of North America. Malacological Publications, Hamburg, MI.

Brice, J., and Lewis, R. (1979). "Mapping of mussel (Unionidae) communities in large streams," American Midland Naturalist 101, 454-55.

Clench, W. J., and van der Schalie, H. (1943). "Notes on naiades from the Green, Salt, and Tradewater Rivers in Kentucky," Michigan Academy of Sciences, Arts, and Letters 29, 223-28.

Cochran, T. G., and Layzer, J. B. (1992). "Effects of commercial exploitation on unionid populations in the Green and Barren Rivers, Kentucky," presented at the 40th Annual Meeting of the North American Benthological Society, 26-29 May 1992, Louisville, KY.

Coker, R. E. (1919). "Fresh-water mussels and mussel industries of the United States," Bulletin of the United States Bureau of Fisheries 13, 75181.

Green, R. H. (1979). Sampling design and statistical methods for environmental biologists. John Wiley \& Sons, New York.

Hughes, R. G. (1986). "Theories and models of species abundance," American Naturalist 128, 879-99.

Hurlbert, S. H. (1984). "Pseudoreplication and the design of ecological field experiments," Ecological Monographs 54, 187-211.

Isom, B. G. (1974). "Mussels of the Green River, Kentucky," transactions of the Kentucky Academy of Sciences 35 (1-2), 55-57.7, 397-425. 
Isom, B. G., and Gooch, C. (1986). "Rationale and sampling design for freshwater mussels, Unionidae, in streams, large rivers, impoundments, and lakes," Rationale for sampling and interpretation of ecological data in the assessment of freshwater ecosystems, ASTM STP 894, B. G. Isom, ed., American Society for Testing and Materials, Philadelphia, PA, 46-59.

Kovalak, W. P., Dennis, S. D., and Bates, J. M. (1986). "Sampling effort required to find rare species of freshwater mussels," Rationale for sampling and interpretation of ecological data in the assessment of freshwater ecosystems, ASTM STP 894, B. G. Isom, ed., American Society for Testing and Materials, Philadelphia, PA, 34-45.

Magurran, A. E. (1988). Ecological diversity and its measurement. Princeton University Press, Princeton, NJ.McNaughton, S. J., and Wolf, L. L. (1973). General ecology. Holt, Rinehart, and Winston, New York.

Miller, A. C., and Nelson, D. A. (1983). "An instruction report on freshwater mussels," Instruction Report El-83-2, U.S. Army Engineer Waterways Experiment Station, Vicksburg, MS.

Miller, A. C., and Payne, B. S. (1988). "The need for quantitative sampling to characterize size demography and density of freshwater mussel communities," Bulletin of the American Malacological Union, Inc., 6, 49-54.

(1991). "Phase II: The impacts of commercial navigation traffic on freshwater mussels at the Zimmer Power Plant - 1989-90 Studies," Technical Report EL-91-12, U.S. Army Engineer Waterways Experiment Station, Vicksburg, MS.

(1992). "The effects of commercial navigation traffic on freshwater mussels in the upper Mississippi River: 1990 Studies," Technical Report EL-92-23, U.S. Army Engineer Waterways Experiment Station, Vicksburg, MS.

Miller, A. C., Payne, B. S., and Hartfield, P. D. (1992). "Characterization of a dense mussel bed in the Big Sunflower River, Mississippi," Journal of the Mississippi Academy of Sciences 37 (3), 8-11.

Miller, A. C., Payne, B. S., Hornbach, D. J., and Ragland, D. V. (1990). "An investigation of the physical effects of increased commercial navigation traffic on freshwater mussels in the upper Mississippi River: Phase I Studies," Technical Report EL-90-3, U.S. Army Engineer Waterways Experiment Station, Vicksburg, MS.

Murray, H. D., and Leonard, A. B. (1962). "Handbook of Unionid mussels in Kansas," Miscellaneous Paper 28, University of Kansas, Department of Zoology, and State Biological Survey, Lawrence, KS.

Ortmann, A. E. (1926). "The naiades of the Green River drainage in Kentucky," Annals of the Carnegie Museum 17 (1), 167-88. 
Payne, B. S., and Miller, A. C. (1989). "Growth and survival of recent recruits to a population of Fusconaia ebena (Bivalvia: Unionidae) in the lower Ohio River," American Midland Naturalist 121, 99-104.Payne, B. S., McMahon, R., Hartfield, P. D., and Miller, A. C. (1989). "Variation in size demography of lotic populations of Corbicula fluminea," The Nautilus 103, 78-82.

Parmalee, P. W. (1967). "The fresh-water mussels of Illinois," Illinois State Museum Popular Science Series 8, 1-108.

Shannon, C. E., and Weaver, W. (1949). The mathematical theory of communication. University of Illinois Press, Urbana, IL.

Stansbery, D. H. (1965). "The naiad fauna of the Green River at Munfordville, Kentucky," Annual Reports of the American Malacological Union for 1965, 13-14.

Starrett, W. C. (1971). "A survey of the mussels (Unionidae) of the Illinois River: a polluted stream," Illinois Natural History Survey Bulletin $30(5), 266-403$.

U.S. Fish and Wildlife Service. (1991). Endangered and Threatened Wildlife and Plants. 50 CFR $17.11 \& 17.12$ (15 July 1991). Office of Endangered Species, Washington, D.C.

Turgeon, D. D., Bogan, A. E., Coan, E. V., Emerson, W. K., Lyons, W. G., Pratt, W. L., Roper, C. F. E., Scheltema, A., Thompson, F. G., and Williams, J. D. (1988). Common and scientific names of aquatic invertebrates from the United States and Canada: mollusks. Committee on Scientific and Vernacular Names of Mollusks of the Council of Systematic Malacologists, American Malacological Union, Bethesda, MD.

Way, C. M., Miller, A. C., and Payne, B. S. (1989). "The influence of physical factors on the distribution and abundance of freshwater mussels (Bivalvia: Unionidae) in the lower Tennessee River," The Nautilus 103, 96-98.

Weiss, J. L. and Layzer, J. B. (1992). "Species composition and abundance of freshwater mussels among various habitats in the Barren River, Kentucky," presented at the 40th Annual Meeting of the North American Benthological Society Meeting, 26-29 May 1992, Louisville, $\mathrm{KY}$.

Williams, J. C. (1969). "Mussel fishery investigations, Tennessee, Ohio and Green Rivers," Project Completion Report for Investigations Projects Conducted Under the Commercial Fisheries Research and Development Act of 1964, U.S. Fish and Wildlife Service and Kentucky Department of Fish and Wildlife Resources. 



\section{Appendix A Results of Qualitative Searches for Mussels in the Green and Barren Rivers, Kentucky, 1992}




\begin{tabular}{|c|c|c|}
\hline \multicolumn{3}{|c|}{$\begin{array}{l}\text { Table A1 } \\
\text { Sites Where Qualitative Searches for Mussels Were Made in } \\
\text { the Green and Barren Rivers, Kentucky, June and July, } 1992^{1}\end{array}$} \\
\hline Dive No. & Date & River Mile \\
\hline \multicolumn{3}{|c|}{ Green River } \\
\hline 1 & 16 June & 107.5 \\
\hline 2 & 16 June & 101.5 \\
\hline 3 & 16 June & 103.7 \\
\hline 4 & 16 June & 105.5 \\
\hline 5 & 16 June & 107.4 \\
\hline \multicolumn{3}{|c|}{ Barren River } \\
\hline 6 & 18 June & 1.5 \\
\hline 7 & 18 June & 2.9 \\
\hline 8 & 18 June & 4.8 \\
\hline 9 & 18 June & 8.7 \\
\hline 10 & 18 June & 6.6 \\
\hline 11 & 18 June & 1.95 \\
\hline 12 & 18 June & 2.05 \\
\hline \multicolumn{3}{|c|}{ Green River } \\
\hline 13 & 19 June & 109.5 \\
\hline 14 & 19 June & 113.8 \\
\hline 15 & 19 June & 115.5 \\
\hline 16 & 19 June & 117.6 \\
\hline 17 & 19 June & 121.5 \\
\hline 18 & 19 June & 129.6 \\
\hline 19 & 20 June & 131.9 \\
\hline 20 & 23 July & 148.6 \\
\hline 21 & 23 July & 148.5 \\
\hline 22 & 23 July & 147.2 \\
\hline 23 & 24 July & 150.2 \\
\hline 24 & 24 July & 155.8 \\
\hline 25 & 24 July & 149.2 \\
\hline 26 & 24 July & 143.9 \\
\hline 27 & 24 July & 137.5 \\
\hline
\end{tabular}




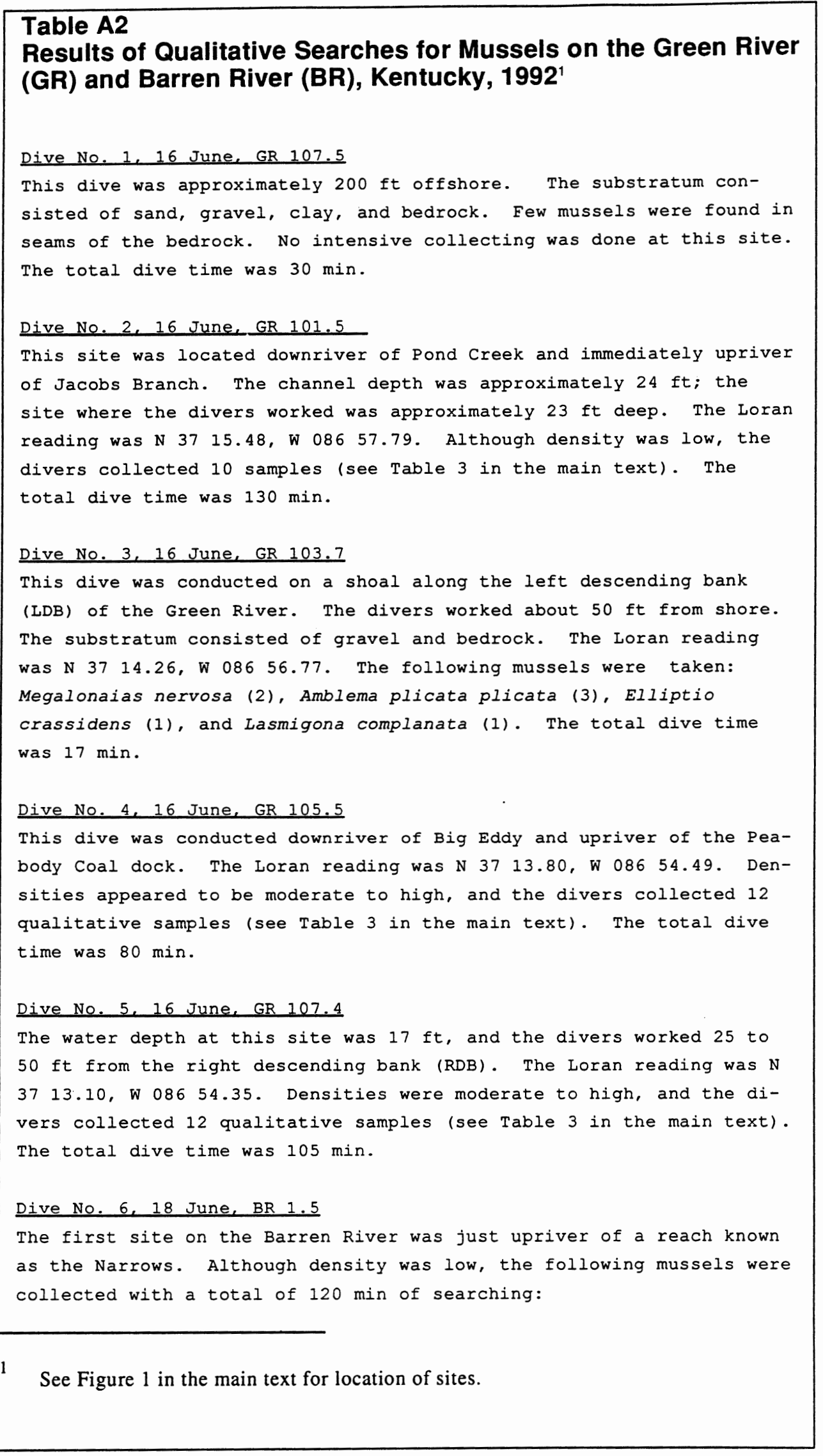




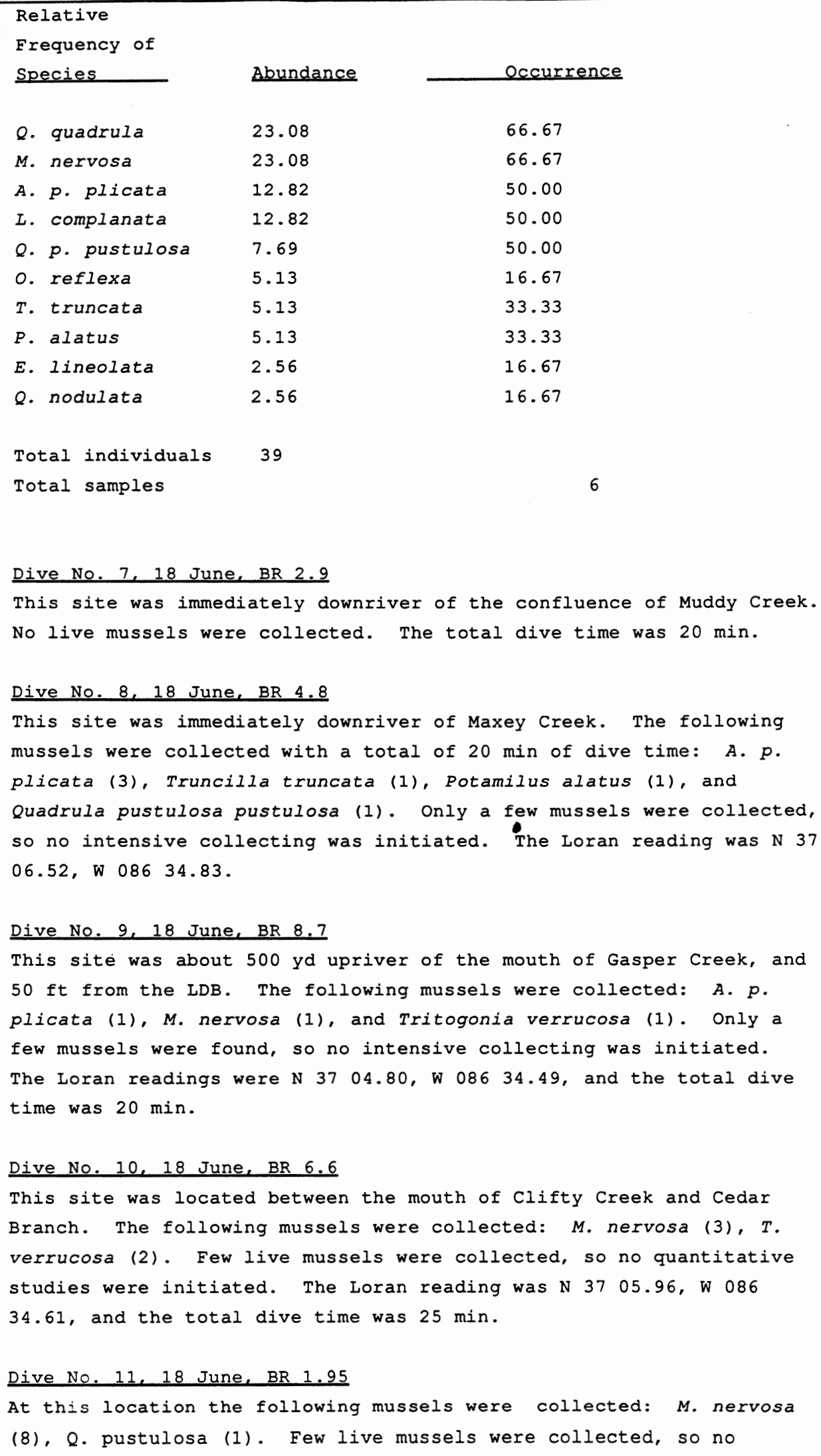

$P$. alatus

16.67

Q. nodulata

Total individuals

Dive No. 7,18 June, BR 2.9

This site was immediately downriver of the confluence of Muddy Creek. No live mussels were collected. The total dive time was $20 \mathrm{~min}$.

Dive No. 8,18 June, $B R 4.8$

This site was immediately downriver of Maxey Creek. The following mussels were collected with a total of $20 \mathrm{~min}$ of dive time: $A . p$. plicata (3), Truncilla truncata (1), Potamilus alatus (1), and Quadrula pustulosa pustulosa (1). Only a few mussels were collected, so no intensive collecting was initiated. The Loran reading was N 37 06.52 , W 08634.83 .

Dive No. 9,18 June, $B R 8.7$

This site was about 500 yd upriver of the mouth of Gasper Creek, and $50 \mathrm{ft}$ from the LDB. The following mussels were collected: $A . p$. plicata (1), M. nervosa (1), and Tritogonia verrucosa (1). Only a few mussels were found, so no intensive collecting was initiated. The Loran readings were $\mathrm{N} 3704.80, \mathrm{~W} 08634.49$, and the total dive time was $20 \mathrm{~min}$.

Dive No. 10,18 June, BR 6.6

This site was located between the mouth of clifty Creek and Cedar Branch. The following mussels were collected: $M$. nervosa (3), T. verrucosa (2). Few live mussels were collected, so no quantitative studies were initiated. The Loran reading was N 3705.96 , W 086 34.61 , and the total dive time was $25 \mathrm{~min}$.

Dive No. 11,18 June, BR 1.95

At this location the following mussels were collected: $M$. nervosa (8), Q. pustulosa (1). Few live mussels were collected, so no 
intensive sampling was initiated. The Loran reading was $\mathrm{N} 3709.19$,

$\mathrm{W} 08636.74$. The total dive time was $20 \mathrm{~min}$.

Dive No. 12,18 June, BR 2.05

This site was approximately 200 to 300 yd upriver of site No. 11 . No mussels were collected by the divers. The Loran reading was $\mathrm{N} 37$ 09.17, W 08636.74 and the total dive time was $20 \mathrm{~min}$.

Dive No. 13,19 June, GR 109.5

This site was directly across from the mouth of Panther Creek. Substratum consisted of sand and gravel. One diver searched for about $10 \mathrm{~min}$ and found no live mussels. The Loran reading was $\mathrm{N} 3713.06$, W 08653.16 .

Dive No. 14,19 June, GR 113.8

This site was immediately offshore of an abandoned ferry. Substratum consisted of sand, gravel, and mud. After searching for $10 \mathrm{~min}$, one diver collected a single $M$. nervosa and one Quadrula quadrula. Because of low density, no intensive sampling was initiated. The Loran was N 3712.48 , W 08648.65 .

Dive No. 15,19 June, GR 115.5

This suite was located at the mouth of Dotson Lake outlet. A single diver searched for $15 \mathrm{~min}$ and found one live $M$. nervosa. Substratum consisted of gravel on top of silt. Because of low density, no intensive sampling was initiated. The Loran reading was $\mathrm{N} 3714.71$, W 086 48.61 .

Dive No. 16,19 June, GR 117.6

This site was upriver of Mud Creek nearing Mining City. The substratum consisted of gravel, sand, logs, and debris. One diver found a single $I$. complanata after $10 \mathrm{~min}$ of searching. The Loran reading was N 3713.71 W 08646.90 .

Dive No. 17,19 June, GR 121.5

This site was opposite the Doolin lake outlet. Ten min of searching by a single diver yielded the following mussels: $M$. nervosa (1), Quadrula nodulata (1), Q. quadrula (1), and L. complanata (1). All collected mussels were small, less than 2 in. maximum shell length. The substratum consisted of hard clay. No intensive sampling was initiated because of low density. The Loran reading was $N 3713.40$, W 08645.00 .

Dive No. 18,19 June, GR 129.6

This dive was behind cromwell Island. It appeared to have once been a good site for mussels. The diver reported high densities of relic shells. No live mussels were collected. The water depth was $27 \mathrm{ft}$. The Loran reading was $N 3719.67$, W 08648.48 . The total dive time was $20 \mathrm{~min}$. 
Dive No. 19,20 June, GR 131.9

The substratum consisted of coarse sand, gravel, and cobble. The water depth was $44 \mathrm{ft}$. No live mussels were found after $15 \mathrm{~min}$ of searching by a single diver. The Loran reading was $N 3719.16, \mathrm{~W} 086$ 46.36 .

Dive No. 20, 23 July, GR 148.6

A single diver searched for $10 \mathrm{~min}$ from the edge of the RDB to a distance three-quarters of the way across the river. Many dead shells were found, but only a single live E. crassidens.

Dive No. 21,23 Julv, GR 148.5

A single diver searched about $10 \mathrm{~min}$ about three-quarters of the distance from the LDB across the river. Along the LDB, the substratum consisted of gravel and mud. In the channel, the substratum consisted of large cobble and stone. Many shells were found, although no live mussels were collected.

Dive No. 22,23 July, GR 147.2

This site was between Fosters Landing and Hatchers Eddy. Two divers worked for $10 \mathrm{~min}$ (total dive time was $20 \mathrm{~min}$ ) and found only three dead shells and no live mussels. In the center of the channel, the substratum consisted of 8 to $10 \mathrm{in.} \mathrm{of} \mathrm{detritus} \mathrm{over} \mathrm{gravel.} \mathrm{Along}$ the LDB, the substratum consisted of clean gravel with no detritus.

Diver No. 23,24 Julv, GR 150.2

Two divers were down for $10 \mathrm{~min}$ (total dive time was $20 \mathrm{~min}$ ) and found a single $M$. nervosa and obliquaria reflexa in the center of the channel where the substratum consisted of gravel. From the RDB to the center of the channel, the substratum consisted of detritus, finegrained sand, and gravel. Along the LDB, the substratum consisted of large cobble.

Dive No. 24,24 Julv, GR 155.8

Two divers were down for $10 \mathrm{~min}$ (total dive time was $20 \mathrm{~min}$ ) and collected the following mussels: $P$. alatus (1), Pleurobema cordatum (1), $Q$. pustulosa (1), and $Q$. Quadrula (1). The substratum along the RDB consisted of sand, and in the center of the channel, the substratum consisted of sand and gravel. Along the LDB, the substratum consisted of cobble and boulders. Current velocity was estimated at 3 to $4 \mathrm{ft} / \mathrm{sec}$.

Dive No. 25,24 July, GR 149.2

One diver worked for $20 \mathrm{~min}$ and collected the following mussels: $M$. nervosa (3), and $L$. complanata (1). The substratum consisted of gravel. This was a pooled section of the river immediately above Lock and Dam 4 . 
Diver No. 26,24 July, GR 143.9

A single diver worked for $20 \mathrm{~min}$ and collected only two $M$. nervosa. Substratum consisted of fine gravel and sand from the RDB to the center of the channel.

Dive No. 27,24 July, GR 137.5

A single diver worked for $20 \mathrm{~min}$ and collected the following mussels: M. nervosa (2), L. complanata (2), P. cordatum (2), Arcidens confragosus (1), and E. crassidens (1). The water depth was $24 \mathrm{ft}$, and the substratum consisted of gravel, small-sized cobble, and sand in the center of the channel. Along the LDB, the substratum consisted of gravel and rock. 


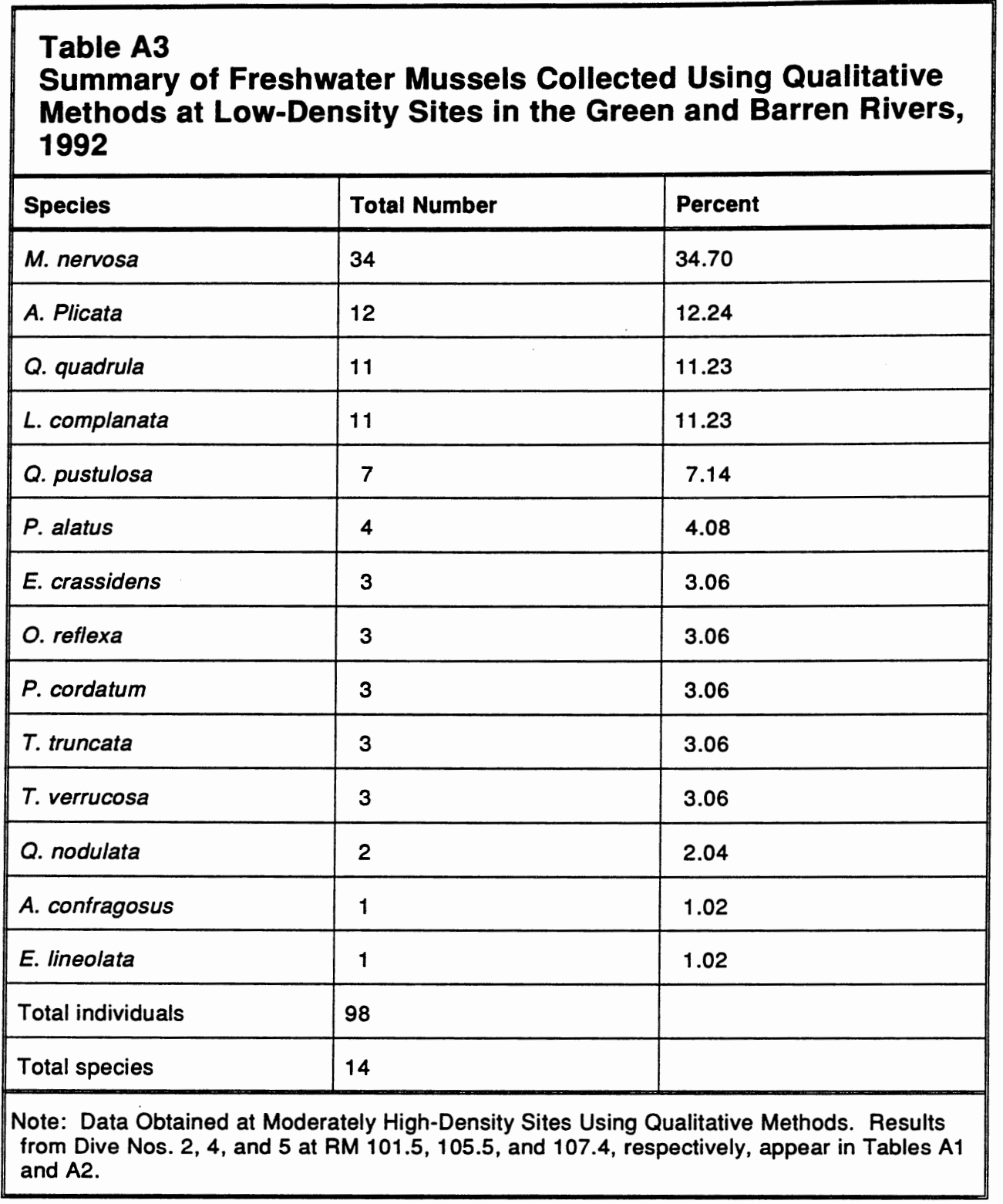




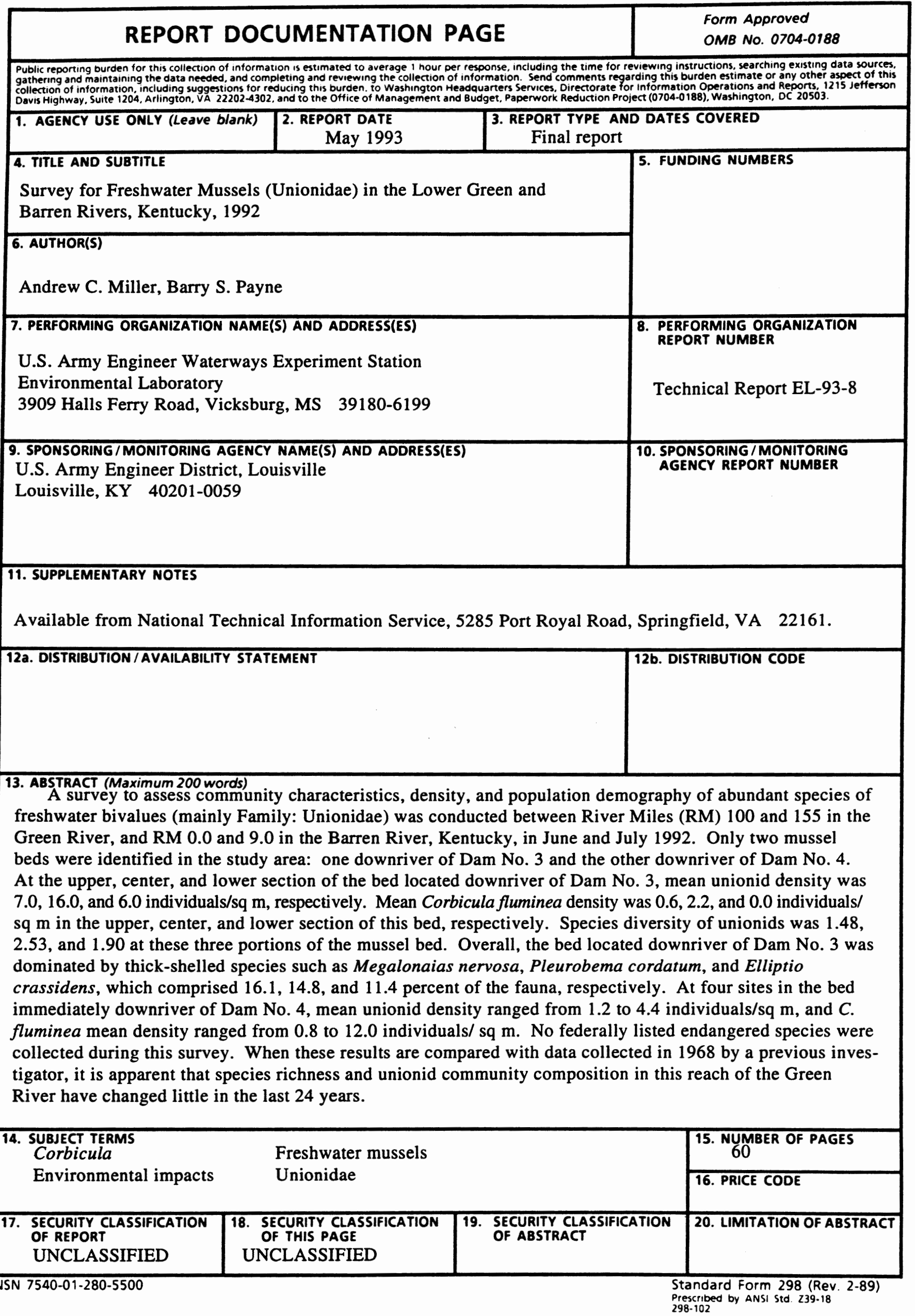


